\title{
Genomics of speech and language disorders
}

\author{
Joaquin Guerra', Ramon Cacabelos ${ }^{2}$ \\ ${ }^{1}$ Neuro-Otolaryngology Unit, Euroespes Biomedical Research Center, Institute of Medical Science and Genomic Medicine, Bergondo \\ 15165, Corunna, Spain. \\ 2Department of Genomic Medicine, Euroespes Biomedical Research Center, Institute of Medical Science and Genomic Medicine, Bergondo \\ 15165, Corunna, Spain.
}

Correspondence to: Dr. Joaquin Guerra, Neuro-Otolaryngology Unit, Euroespes Biomedical Research Center, Institute of Medical Science and Genomic Medicine, Bergondo 15165, Corunna, Spain. E-mail: neuroorl@euroespes.com

How to cite this article: Guerra J, Cacabelos R. Genomics of speech and language disorders. J Trans/ Genet Genom 2019;3:9. https://doi.org/10.20517/jtgg.2018.03

Received: 15 Dec 2018 First Decision: 8 Apr 2019 Revised: 22 Apr 2019 Accepted: 7 May 2019 Published: 21 Jun 2019

Science Editor: Sheng-Ying Qin Copy Editor: Cai-Hong Wang Production Editor: Huan-Liang Wu

\begin{abstract}
Multiple factors involve speech and language. Investigating animal models, mainly through songbirds, has allowed a better understanding of the verbal communication process. Speech disorders, such as childhood apraxia of speech, dysarthria or stuttering, along with language disorders, like aphasia, dyslexia or developmental language disorder are the main examples. More complex syndromes such as Autism-spectrum disorders, Down's syndrome or Fragile X syndrome have more variable features. Genetic factors, such as hereditary or de novo mutations may influence the development of all of these conditions. Besides, most of speech and language disorders are implicated in neurodevelopment with molecular mechanisms and pathways that interact with each other, and there may be co-morbidity with other communication disorders or phenotypes unrelated to communication. Genes with heterogeneous functions in speech and language such as FOXP1, FOXP2, KIAAO319, ROBO1, APOE or CNTNAP2 are some examples. Epigenetic factors, especially microRNAs, influence the expressiveness. The genomics of these disorders allows us to understand language acquisition, carry out early detection strategies, genetic counseling and optimize future treatments, not only in communication disorders but also the neurological alterations that incorporate these mutations.
\end{abstract}

Keywords: Genomics, epigenetic, speech, language, dysarthria, stuttering, aphasia, FOXP2

\section{INTRODUCTION}

The language process requires three structures of the central nervous system: cortex, basal ganglia, and cerebellum $^{[1]}$. The primary language pathway begins at Wernicke's area, in the posterior temporal lobe. This pathway collects information from the visual and auditory cortex and it is responsible for understanding

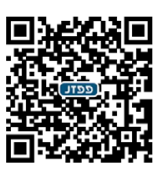


language. The arcuate fasciculus connects Wernicke's to Broca's area, in the inferior-posterior frontal lobe. This area generates language and starts the muscular activity involved in speech. The second language pathway drives through the angular and supramarginal gyrus, region located in the posterior parietal lobe, and connects with Broca's and Wernicke's areas ${ }^{[2]}$. Syntax-related networks are located in the opercular/ triangular parts of the left inferior frontal gyrus and lateral premotor cortex. The basal ganglia are involved in prosodic modulation and language acquisition, and are responsible for language learning in adults ${ }^{[3]}$. Finally, the cerebellum is also required in the processing of expressive and receptive language, and writing skills ${ }^{[4]}$.

Sometimes, the causes of speech and language disorders (SLD) are acquired (due to stroke or trauma). The characteristics will depend on the damaged nerve structures and the degree of involvement. However, genetic factors involve various pathologies that may associate SLD ${ }^{[5,6]}$ [Table 1]. Genetic factors associated with language contribute to various molecular, cellular and regulatory processes that shape neuronal architecture through neuronal migration, axon guidance, brain network development including connectivity and determine neurodevelopmental characteristics ${ }^{[7]}$. The same gene may be linked to different disorders, showing the great complexity of the speech and language process ${ }^{[6]}$. Also, language disabilities in children may appear along with other developmental diagnoses, such as intellectual impairments, hearing loss, and syndromes such as autism spectrum disorders (ASD), Down's and Fragile X syndromes. The construction of a knowledge base for genetic etiology makes it possible to identify patients with genetic risk and motivate early intervention programmes ${ }^{[8]}$. In addition, it is mandatory to identify those epigenetic factors that characterize language and speech ${ }^{[9,10]}$.

Because genomic knowledge of these disorders is limited, the aim of this review is to allow a rational classification of the main causes of both early and late-onset speech and language disorders and characterize their genomic and epigenetic background. Based on the definitions of each case, the genes involved in each language and speech phenotype will be described. We will observe the complex network of genetic pathways involving different disorders, and note how these disorders have important limitations due to lack of replication or information. Finally, we will attempt to demonstrate briefly the importance of these disorders as part of other more complex pathologies and how the knowledge of these genes may be useful as markers of early diagnosis and prognosis.

\section{GENOMICS OF SPEECH DISORDERS}

\section{Dysarthria}

Dysarthria is a motor speech disorder that causes poor coordination of the articulation with pharyngeal, laryngeal, lingual or facial muscle involvement. This condition is due to alterations that affect the cranial nerves, neuromuscular, cerebellar, basal ganglia or cortical-bulbar tract diseases, while it preserves the cortical function of speech $^{[11]}$. Dysarthria is divided into six groups: flaccid, ataxia, spastic, hypokinetic, hyperkinetic and mixed ${ }^{[12]}$ [Table 2]. Little is known about the role of dysarthria in different neurological pathologies, so we will focus on some of the genes that have been identified so far, their phenotypic characteristics and their potential applications.

\section{Flaccid dysarthria}

Flaccid dysarthria relates to disorders of the lower motor neuron system and/or muscle. It generates continuous expiratory speech, diplophonia, and hypernasality ${ }^{[12]}$. Myasthenia gravis, amyotrophic lateral sclerosis, or Prader-Willi syndrome are examples of flaccid dysarthria ${ }^{[13]}$.

Myasthenia gravis: Myasthenia gravis (MG) is an autoimmune disorder, caused by antibody formation at the neuromuscular junction. CHRNA1 gene encodes the alpha subunit of the acetylcholine receptor, 
Table 1. Genes potentially involved in speech and language disorders included in this review

\begin{tabular}{|c|c|c|c|c|c|c|c|}
\hline Gene & Name & Locus & Disorder & Methods & Comments & Other phenotypes & Ref. \\
\hline $\mathrm{ABCC} 13$ & $\begin{array}{l}\text { ATP-binding cassette } \\
\text { subfamily C, member } \\
13\end{array}$ & $21 q 11.2$ & DLD & GWAS & & & {$[125]$} \\
\hline ANKK1 & $\begin{array}{l}\text { Ankyrin Repeat } \\
\text { And Kinase Domain } \\
\text { Containing } 1\end{array}$ & $11 q 23.2$ & SSD & CG & & & [162] \\
\hline ANKRD12 & $\begin{array}{l}\text { Ankyrin Repeat } \\
\text { Domain } 12\end{array}$ & $18 p 11.22$ & CAS & WES & $\begin{array}{l}\text { Additive } \\
\text { effects } \\
\text { Uncertain } \\
\text { significance } \\
\text { according to } \\
\text { Thevenon et } \\
\text { al. }{ }^{[91]} 2012\end{array}$ & & {$[88,91]$} \\
\hline AP4E1 & $\begin{array}{l}\text { Adaptor Related } \\
\text { Protein Complex } 4 \\
\text { Subunit Epsilon } 1\end{array}$ & $15 q 21.2$ & ST & WES & $\begin{array}{l}\text { Replicated in } \\
\text { several } \\
\text { ethnic groups }\end{array}$ & $\begin{array}{l}\text { - Spastic paraplegia } 51, \\
\text { autosomal recessive }\end{array}$ & {$[68]$} \\
\hline APOE & Apolipoprotein E & 19q13.32 & AP & $\mathrm{TM}$ & $\begin{array}{l}\text { Different } \\
\text { phenotype } \\
\text { expression } \\
\text { according to its } \\
\text { alleles }\end{array}$ & $\begin{array}{l}\text { - Alzheimer disease-2 } \\
\text { - Hyperlipoproteinemia } \\
\text { type III } \\
\text { - Lipoprotein } \\
\text { glomerulopathy } \\
\text { - Sea-blue histiocyte } \\
\text { disease } \\
\text { - Macular degeneration, } \\
\text { age-related } \\
\text { - Coronary artery } \\
\text { disease, severe, } \\
\text { susceptibility to }\end{array}$ & [105-108] \\
\hline ARL17 A/B & $\begin{array}{l}\text { ADP ribosylation factor } \\
\text { like GTPase 17A/B }\end{array}$ & $\begin{array}{l}17 q 21.13 / \\
17 q 21.31\end{array}$ & $\mathrm{DL}$ & CG & & & {$[166]$} \\
\hline ATP13A4 & ATPase 13A4 & $3 q 29$ & CAS & WES & $\begin{array}{l}\text { Additive } \\
\text { effects }\end{array}$ & & {$[90]$} \\
\hline ATP2C2 & $\begin{array}{l}\text { ATPase Secretory } \\
\text { Pathway } \mathrm{Ca}^{2+} \\
\text { Transporting } 2\end{array}$ & $16 q 24.1$ & $\begin{array}{l}\text { DLD } \\
\text { ASD }\end{array}$ & GWLATM CG & & & {$[120,191]$} \\
\hline BDNF & $\begin{array}{l}\text { Brain Derived } \\
\text { Neurotrophic Factor }\end{array}$ & $11 p 14.1$ & SSD & CG & & & [162] \\
\hline C2ORF3 & $\begin{array}{l}\text { GC-Rich Sequence } \\
\text { DNA-Binding Factor } 2\end{array}$ & $2 \mathrm{p} 12$ & $\mathrm{DL}$ & GWLA & $\begin{array}{l}\text { Coregulator } \\
\text { Replicated }\end{array}$ & & {$[158]$} \\
\hline $\mathrm{CDH} 18$ & Cadherin 18 & $5 p 14.3$ & CAS & WES & & & [88] \\
\hline $\mathrm{CHD} 3$ & $\begin{array}{l}\text { Chromodomain } \\
\text { Helicase DNA Binding } \\
\text { Protein } 3\end{array}$ & 17p13.1 & CAS & WGS & & & [89] \\
\hline CHRNA3 & $\begin{array}{l}\text { Cholinergic Receptor } \\
\text { Nicotinic Alpha } 3 \\
\text { Subunit }\end{array}$ & $15 q 25.1$ & SSD & CG & & $\begin{array}{l}\text { - Lung cancer } \\
\text { susceptibility } 2\end{array}$ & {$[162]$} \\
\hline CMIP & C-Maf Inducing Protein & $16 q 23.2-q 23.3$ & $\begin{array}{l}\text { DLD, DL, } \\
\text { ASD }\end{array}$ & TM & Replicated & & {$[120,161,191]$} \\
\hline CNTNAP1 & $\begin{array}{l}\text { Contactin Associated } \\
\text { Protein } 1\end{array}$ & $17 q 21.2$ & CAS & WES & $\begin{array}{l}\text { Additive } \\
\text { effects } \\
\text { Not associated } \\
\text { with ST }\end{array}$ & $\begin{array}{l}\text { - Lethal congenital } \\
\text { contracture syndrome } 7\end{array}$ & [90] \\
\hline CNTNAP2 & $\begin{array}{l}\text { Contactin Associated } \\
\text { Protein } 2\end{array}$ & $7 q 35-q 36$ & $\begin{array}{l}\text { DLD, } \\
\text { CAS, } \\
\text { ST DT } \\
\text { ASD? }\end{array}$ & GWAS CG & $\begin{array}{l}\text { Replicated in } \\
\text { several SLD } \\
\text { Not associated } \\
\text { with } \\
\text { psychiatric } \\
\text { conditions }\end{array}$ & $\begin{array}{l}\text { - Cortical dysplasia-focal } \\
\text { epilepsy syndrome } \\
\text { - Pitt-Hopkins like } \\
\text { syndrome } 1\end{array}$ & {$[60,76,90,115,117,180]$} \\
\hline COL4A2 & $\begin{array}{l}\text { Collagen Type IV alpha } \\
2\end{array}$ & $13 q 34$ & DLD & GWAS & & $\begin{array}{l}\text { - Porencephaly } 2 \\
\text { - Susceptibility } \\
\text { to hemorrhage, } \\
\text { intracerebral }\end{array}$ & [128] \\
\hline COMT & $\begin{array}{l}\text { Cathecol-O- } \\
\text { MethylTransferase }\end{array}$ & $22 q 11.21$ & $\mathrm{DL}$ & CG & & $\begin{array}{l}\text { - Susceptibility to panic } \\
\text { disorder } \\
\text { - Susceptibility to } \\
\text { Schizophrenia }\end{array}$ & {$[160]$} \\
\hline CTTNBP2 & $\begin{array}{l}\text { Cortactin Binding } \\
\text { Protein } 2\end{array}$ & $7 q 31.31$ & ASD & $\mathrm{TM}$ & & & {$[186]$} \\
\hline
\end{tabular}




\begin{tabular}{|c|c|c|c|c|c|c|c|}
\hline CYP19A1 & $\begin{array}{l}\text { Cytochrome P450 } \\
\text { Family } 19 \text { Subfamily A } \\
\text { Member } 1\end{array}$ & $15 q 21.2$ & SSD & TM & & $\begin{array}{l}\text { - Aromatase deficiency } \\
\text { - Aromatase excess } \\
\text { syndrome }\end{array}$ & [99] \\
\hline DCDC2 & $\begin{array}{l}\text { Doublecortin Domain } \\
\text { Containing } 2\end{array}$ & $6 p 22.3$ & SSD, DL & CG & & $\begin{array}{l}\text { - Sclerosing cholangitis, } \\
\text { neonatal } \\
\text { - Nephronophthisis } 19 \\
\text { - Deafness, autosomal } \\
\text { recessive } 66\end{array}$ & {$[149-151,154]$} \\
\hline DGK1 & $\begin{array}{l}\text { Diacylglycerol Kinase } \\
\text { Epsilon }\end{array}$ & $17 q 22$ & DL & CG & & $\begin{array}{l}\text { - Nephrotic syndrome, } \\
\text { type } 7 \\
\text { - Susceptibility to } \\
\text { hemolytic uremic } \\
\text { syndrome, atypical }\end{array}$ & [154] \\
\hline DRD2 & $\begin{array}{l}\text { Dopamine Receptor } \\
\text { D2 }\end{array}$ & $11 \mathrm{q} 23.2$ & SSD & CG & & & [162] \\
\hline DYM & Dymeclin & $18 q 21.1$ & $\mathrm{DL}$ & TM & & $\begin{array}{l}\text { - Dyggve-Melchior- } \\
\text { Clausen disease } \\
\text { - Smith-McCort } \\
\text { dysplasia }\end{array}$ & [154] \\
\hline DYX1C1 & $\begin{array}{l}\text { Dynein Axonemal } \\
\text { Assembly Factor } 4\end{array}$ & $15 q 21.3$ & $\mathrm{DL}, \mathrm{SSD}$ & TM & & $\begin{array}{l}\text { - Ciliary dyskinesia, } \\
\text { primary, } 25\end{array}$ & [144-146] \\
\hline DYX2 & & & $\begin{array}{l}\mathrm{DL} \\
\mathrm{ASD}\end{array}$ & TM & & & [191] \\
\hline DYX3 & $\begin{array}{l}\text { Dyslexia Susceptibility } \\
3\end{array}$ & 2p16-p15 & $\mathrm{DL}$ & TM & & & [139] \\
\hline DYX5 & $\begin{array}{l}\text { Dyslexia Susceptibility } \\
5\end{array}$ & 3p12-q13 & $\mathrm{DL}, \mathrm{SSD}$ & WGS & & & {$[98,140]$} \\
\hline DYX6 & $\begin{array}{l}\text { Dyslexia Susceptibility } \\
6\end{array}$ & $18 p 11.2$ & $\mathrm{DL}$ & GWA & & & [141] \\
\hline DYX8 & $\begin{array}{l}\text { Dyslexia Susceptibility } \\
8\end{array}$ & 1p36-p34 & $\mathrm{DL}, \mathrm{SSD}$ & TM & Replicated & & {$[142]$} \\
\hline DYX9 & $\begin{array}{l}\text { Dyslexia Susceptibility } \\
9\end{array}$ & $\mathrm{Xq27.3}$ & $\mathrm{DL}$ & GWA & & & [143] \\
\hline ELKS & $\begin{array}{l}\text { ELK1, ETS Transcription } \\
\text { Factor }\end{array}$ & $12 p 13.33$ & CAS & CG & & & [91] \\
\hline ELP4 & $\begin{array}{l}\text { Elongator } \\
\text { Acetyltransferase } \\
\text { Complex Subunit } 4\end{array}$ & $11 p 13$ & SSD & CG & & - Aniridia 2 & {$[100]$} \\
\hline EN2 & Engrailed 2 & $7 q 36.3$ & ASD & TM & & & [187] \\
\hline FLCN & Folliculin & 7p11.2 & CAS & GWAS & $\begin{array}{l}\text { Additive } \\
\text { effects }\end{array}$ & $\begin{array}{l}\text { - Birt-Hogg-Dube } \\
\text { syndrome } \\
\text { - Colorectal cancer, } \\
\text { somatic } \\
\text { - Pneumothorax, primary } \\
\text { spontaneous } \\
\text { - Renal carcinoma, } \\
\text { chromophobe, somatic }\end{array}$ & [88] \\
\hline FOXP1 & Forkhead Box P1 & $3 p 13$ & $\begin{array}{l}\text { CAS, DT, } \\
\text { DLD, ASD }\end{array}$ & $\begin{array}{l}\text { TM } \\
\text { CS }\end{array}$ & & & {$[81,86,87,179]$} \\
\hline FOXP2 & Forkhead Box P2 & $7 q 31.1$ & CAS, SSD & $\begin{array}{l}\text { GWASGWLA } \\
\text { TM }\end{array}$ & $\begin{array}{l}\text { First gene } \\
\text { identified, } \\
\text { replicated in } \\
\text { several SLD } \\
\text { Not associated } \\
\text { with ASD and } \\
\text { ST }\end{array}$ & & $\begin{array}{l}{[75,81,82-85,106,155,} \\
172,181,203]\end{array}$ \\
\hline GCFC2 & Transcription factor 9 & $2 \mathrm{p} 12$ & ASD & CG & & & [191] \\
\hline GLI3 & $\begin{array}{l}\text { GLI Family Zinc Finger } \\
3\end{array}$ & 7p14.1 & AP & GWAS & & $\begin{array}{l}\text { - Greig } \\
\text { cephalopolysyndactyly } \\
\text { syndrome } \\
\text { - Pallister-Hall } \\
\text { syndrome } \\
\text { - Polydactyly, postaxial, } \\
\text { types A1 and B } \\
\text { - Polydactyly, preaxial, } \\
\text { type IV } \\
\text { - Hypothalamic } \\
\text { hamartomas, somatic }\end{array}$ & [109] \\
\hline GLP2R & $\begin{array}{l}\text { Glucagon Like Peptide } \\
2 \text { Receptor }\end{array}$ & 17p13.1 & CAS, ASD & WES & $\begin{array}{l}\text { Additive } \\
\text { effects }\end{array}$ & & {$[88]$} \\
\hline
\end{tabular}




\begin{tabular}{|c|c|c|c|c|c|c|c|}
\hline GNPTAB & $\begin{array}{l}\text { N-Acetylglucosamine- } \\
\text { 1-Phosphate } \\
\text { Transferase Subunits } \\
\text { Alpha And Beta }\end{array}$ & $12 \mathrm{q} 23.2$ & ST & GWLA CG & Replicated & $\begin{array}{l}\text { - Mucolipidosis II alpha/ } \\
\text { beta } \\
\text { - Mucolipidosis III } \\
\text { alpha/beta }\end{array}$ & {$[69]$} \\
\hline GNPTG & $\begin{array}{l}\text { N-Acetylglucosamine- } \\
\text { 1-Phosphate } \\
\text { Transferase Subunit } \\
\text { Gamma }\end{array}$ & $16 \mathrm{p} 13.3$ & ST & CG & Replicated & $\begin{array}{l}\text { - Mucolipidosis III } \\
\text { gamma }\end{array}$ & [69] \\
\hline GRN & Granulin Precursor & $17 q 21.31$ & AP & CG & & $\begin{array}{l}\text { - Ceroid lipofuscinosis, } \\
\text { neuronal } \\
\text { - Frontotemporal lobar } \\
\text { degeneration with } \\
\text { ubiquitin-positive } \\
\text { inclusions }\end{array}$ & [111] \\
\hline HRAS & $\begin{array}{l}\text { HRas Proto-Oncogene, } \\
\text { GTPase }\end{array}$ & $11 \mathrm{p} 15.5$ & ASD & CG & & $\begin{array}{l}\text { - Congenital myopathy } \\
\text { with excess of muscle } \\
\text { spindles } \\
\text { - Costello syndrome } \\
\text { - Schimmelpenning- } \\
\text { Feuerstein-Mims } \\
\text { syndrome, somatic } \\
\text { mosaic } \\
\text { - Bladder cancer, } \\
\text { somatic } \\
\text { - Nevus sebaceous } \\
\text { or woolly hair nevus, } \\
\text { somatic } \\
\text { - Spitz nevus or nevus } \\
\text { spilus, somatic } \\
\text { - Thyroid carcinoma, } \\
\text { follicular, somatic }\end{array}$ & [189] \\
\hline KAT6A & $\begin{array}{l}\text { Lysine } \\
\text { Acetyltransferase } 6 \mathrm{~A}\end{array}$ & 8p11.21 & CAS & WGS & & $\begin{array}{l}\text { - Mental retardation, } \\
\text { autosomal dominant } 32\end{array}$ & [89] \\
\hline KIAA0319 & - & $6 p 22.3$ & $\begin{array}{l}\text { DL, SSD, } \\
\text { DLD, } \\
\text { CAS, } \\
\text { ASD }\end{array}$ & $\begin{array}{l}\text { WES, } \\
\text { GWAS }\end{array}$ & & & {$[90,153-155,191,208]$} \\
\hline KIAA1267 & $\begin{array}{l}\text { KAT8 Regulatory NSL } \\
\text { complex, subunit } 1\end{array}$ & $17 q 21.13$ & $\mathrm{DL}$ & CG & & $\begin{array}{l}\text { - Koolen-De Vries } \\
\text { syndrome }\end{array}$ & [166] \\
\hline LRRC37A & $\begin{array}{l}\text { Leucine rich repeat } \\
\text { containing protein } 37 \mathrm{~A}\end{array}$ & $17 q 21.31$ & $\mathrm{DL}$ & CG & & & [166] \\
\hline MC5R & $\begin{array}{l}\text { Melanocortin } 5 \\
\text { receptor }\end{array}$ & $18 p 11.21$ & $\mathrm{DL}$ & CG & & & [154] \\
\hline MED13L & $\begin{array}{l}\text { Mediator Complex } \\
\text { Subunit } 13 \text { Like }\end{array}$ & $12 q 24.21$ & ASD & CG & & $\begin{array}{l}\text { - Transposition of the } \\
\text { great arteries, dextro- } \\
\text { looped } 1 \\
\text { - Mental retardation and } \\
\text { distinctive facial features } \\
\text { with or without cardiac } \\
\text { defects }\end{array}$ & [177] \\
\hline MET & $\begin{array}{l}\text { MET Proto-Oncogene, } \\
\text { Receptor Tyrosine } \\
\text { Kinase }\end{array}$ & $7 q 31.2$ & ASD & CG & & $\begin{array}{l}\text { - Deafness, autosomal } \\
\text { recessive } 97 \\
\text { - Hepatocellular } \\
\text { carcinoma, childhood } \\
\text { type, somatic } \\
\text { - Renal cell carcinoma, } \\
\text { papillary, 1, familial and } \\
\text { somatic } \\
\text { - Osteofibrous dysplasia, } \\
\text { susceptibility to }\end{array}$ & {$[184,185]$} \\
\hline MRPL19 & $\begin{array}{l}\text { Mitochondrial } \\
\text { Ribosomal Protein L19 }\end{array}$ & $2 p 12$ & $\mathrm{DL}$ & GWLA & $\begin{array}{l}\text { Coregulator } \\
\text { Replicated }\end{array}$ & & {$[158,191]$} \\
\hline MYO10 & Myosin X & $5 p 15.1$ & CAS & WES & $\begin{array}{l}\text { Additive } \\
\text { effects }\end{array}$ & & [88] \\
\hline NAGPA & $\begin{array}{l}\text { N-Acetylglucosamine- } \\
\text { 1-Phosphodiester } \\
\text { Alpha-N- } \\
\text { Acetylglucosaminidase }\end{array}$ & $16 p 13.3$ & ST & CG & Replicated & & [69] \\
\hline NBEA & Neurobeachin & $13 q 13.3$ & ASD & CG & & & [188] \\
\hline NCOR1 & $\begin{array}{l}\text { Nuclear Receptor } \\
\text { Corepressor } 1\end{array}$ & 17p12-p11 & CAS & WES & $\begin{array}{l}\text { Additive } \\
\text { effects }\end{array}$ & & {$[88]$} \\
\hline NDST4 & $\begin{array}{l}\text { N-Deacetylase And } \\
\text { N-Sulfotransferase } 4\end{array}$ & $4 q 26$ & DLD & GWAS & & & [128] \\
\hline
\end{tabular}




\begin{tabular}{|c|c|c|c|c|c|c|c|}
\hline NEDD4L & $\begin{array}{l}\text { Neural Precursor } \\
\text { Cell Expressed, } \\
\text { Developmentally } \\
\text { Down-Regulated } \\
\text { 4-Like, E3 Ubiquitin } \\
\text { Protein Ligase }\end{array}$ & $18 q 21.31$ & DL & CG & & $\begin{array}{l}\text { - Periventricular nodular } \\
\text { heterotopia } 7\end{array}$ & [154] \\
\hline NEK8 & $\begin{array}{l}\text { NIMA Related Kinase } \\
8\end{array}$ & $17 q 11.2$ & CAS & WES & $\begin{array}{l}\text { Additive } \\
\text { effects }\end{array}$ & $\begin{array}{l}\text { - Renal-hepatic- } \\
\text { pancreatic dysplasia } 2 \\
\text { - Nephronophthisis }\end{array}$ & [88] \\
\hline NFXL1 & $\begin{array}{l}\text { Nuclear Transcription } \\
\text { Factor, X-Box Binding } \\
\text { Like } 1\end{array}$ & $4 p 12$ & DLD & WES & & & [130] \\
\hline NIPBL & $\begin{array}{l}\text { NIPBL, Cohesin } \\
\text { Loading Factor }\end{array}$ & $5 q 13.2$ & CAS & WES & $\begin{array}{l}\text { Additive } \\
\text { effects }\end{array}$ & $\begin{array}{l}\text { - Cornelia de Lange } \\
\text { syndrome } 1\end{array}$ & [88] \\
\hline NOP9 & $\begin{array}{l}\text { NOP9 Nucleolar } \\
\text { Protein }\end{array}$ & $14 q 12$ & DLD & GWAS & & & [129] \\
\hline NSF & $\begin{array}{l}\mathrm{N} \text {-ethylmaleimide } \\
\text { sensitive factor }\end{array}$ & $17 q 21.31$ & $\mathrm{DL}$ & CG & & & [166] \\
\hline NSFP1 & $\begin{array}{l}\mathrm{N} \text {-ethylmaleimide } \\
\text { sensitive factor } \\
\text { pseudogene } 1\end{array}$ & $17 q 21.31$ & DL & CG & Pseudo-gene & & [166] \\
\hline PAX6 & Paired Box 6 & $11 p 13$ & SSD & CG & & $\begin{array}{l}\text { - Coloboma of optic } \\
\text { nerve } \\
\text { - Coloboma, ocular } \\
\text { - Morning glory disc } \\
\text { anomaly } \\
\text { - Aniridia } \\
\text { - Anterior segment } \\
\text { dysgenesis 5, multiple } \\
\text { subtypes } \\
\text { - Cataract with late- } \\
\text { onset corneal dystrophy } \\
\text { - Foveal hypoplasia } 1 \\
\text { - Keratitis } \\
\text { - Optic nerve hypoplasia }\end{array}$ & [100] \\
\hline PCDH11X & $\begin{array}{l}\text { Protocadherin } 11 \\
\text { X-linked }\end{array}$ & Xq21.31 & DL & CG & & & [165] \\
\hline PSEN1 & Presenilin 1 & $14 q 24.2$ & AP & CG & & $\begin{array}{l}\text { - Acne inversa, familial, } \\
3 \\
\text { - Alzheimer disease, } \\
\text { type } 3 \\
\text { - Alzheimer disease, } \\
\text { type } 3 \text {, with spastic } \\
\text { paraparesis and apraxia } \\
\text { - Alzheimer disease, } \\
\text { type 3, with spastic } \\
\text { paraparesis and unusual } \\
\text { plaques } \\
\text { - Cardiomyopathy, } \\
\text { dilated, } 1 \cup \\
\text { - Dementia, } \\
\text { frontotemporal } \\
\text { - Pick disease }\end{array}$ & [109] \\
\hline PTEN & $\begin{array}{l}\text { Phosphatase And } \\
\text { Tensin Homolog }\end{array}$ & $10 q 23.31$ & ASD & CG & & $\begin{array}{l}\text { - Bannayan-Riley- } \\
\text { Ruvalcaba syndrome } \\
\text { - Cowden syndrome } 1 \\
\text { - Lhermitte-Duclos } \\
\text { syndrome } \\
\text { - Macrocephaly/autism } \\
\text { syndrome } \\
\text { - PTEN hamartoma } \\
\text { tumor syndrome } \\
\text { - VATER association } \\
\text { with macrocephaly and } \\
\text { ventriculomegaly } \\
\text { - Glioma susceptibility } 2 \\
\text { - Meningioma } \\
\text { - Prostate cancer, } \\
\text { somatic }\end{array}$ & [190] \\
\hline
\end{tabular}




\begin{tabular}{|c|c|c|c|c|c|c|c|}
\hline ROBO1 & $\begin{array}{l}\text { Roundabout Guidance } \\
\text { Receptor } 1\end{array}$ & $3 p 12.3$ & $\begin{array}{l}\text { SSD, DL, } \\
\text { ASD }\end{array}$ & GWAS & & & {$[100,140,157$} \\
\hline ROBO2 & $\begin{array}{l}\text { Roundabout Guidance } \\
\text { Receptor } 2\end{array}$ & $3 p 12.3$ & DLD, DL & GWAS & & - Vesicoureteral reflux 2 & {$[127,131]$} \\
\hline SETBP1 & SET Binding Protein 1 & $18 \mathrm{q} 12.3$ & CAS, DLD & WGS & & $\begin{array}{l}\text { - Schinzel-Giedion } \\
\text { midface retraction } \\
\text { syndrome } \\
\text { - Mental retardation, } \\
\text { autosomal dominant } 29\end{array}$ & [89] \\
\hline SETD1A & $\begin{array}{l}\text { SET Domain } \\
\text { Containing } 1 \mathrm{~A}\end{array}$ & 16p11.2 & CAS & WGS & $\begin{array}{l}\text { Newbury et al. } \\
\text { found locus }\end{array}$ & & [89] \\
\hline SETX & Sanataxin & $9 q 34.12$ & CAS, DT & WES & $\begin{array}{l}\text { Additive } \\
\text { effects }\end{array}$ & $\begin{array}{l}\text { - Amyotrophic lateral } \\
\text { sclerosis } 4 \text {, juvenile } \\
\text { - Spinocerebellar ataxia, } \\
\text { autosomal recessive } 1\end{array}$ & {$[20,90]$} \\
\hline SMCR8 & $\begin{array}{l}\text { Smith-Magenis } \\
\text { Syndrome } \\
\text { Chromosome Region, } \\
\text { Candidate } 8\end{array}$ & 11p11.2 & CAS & WES & $\begin{array}{l}\text { Additive } \\
\text { effects }\end{array}$ & & {$[88]$} \\
\hline SRPX2 & $\begin{array}{l}\text { Sushi Repeat } \\
\text { Containing Protein } \\
\text { X-Linked } 2\end{array}$ & Xq22.1 & ASD & CG & & $\begin{array}{l}\text { - Rolandic epilepsy, } \\
\text { mental retardation, and } \\
\text { speech dyspraxia }\end{array}$ & {$[173,174]$} \\
\hline TDP-43 & $\begin{array}{l}\text { TAR DNA Binding } \\
\text { Protein }\end{array}$ & $1 \mathrm{p} 36.22$ & AP & CG & & & [111] \\
\hline TNRC6B & $\begin{array}{l}\text { Trinucleotide Repeat } \\
\text { Containing 6B }\end{array}$ & 22q13.1 & CAS & WGS & & & [89] \\
\hline TTRAP & $\begin{array}{l}\text { Tyrosyl-DNA } \\
\text { Phosphodiesterase } 2\end{array}$ & $6 p 22.3$ & DL & GWAS & & $\begin{array}{l}\text { - Spinocerebellar ataxia, } \\
\text { autosomal recessive } 23\end{array}$ & {$[99,155]$} \\
\hline WDR5 & WD Repeat Domain 5 & $9 q 34.2$ & CAS & WGS & & & [89] \\
\hline ZFHX4 & $\begin{array}{l}\text { Zinc Finger Homeobox } \\
4\end{array}$ & $8 q 21.13$ & CAS & WGS & & - Ptosis congenital & [89] \\
\hline ZGRF1 & $\begin{array}{l}\text { Zinc Finger GRF-Type } \\
\text { Containing } 1\end{array}$ & $15 q 25.1$ & CAS & WES & $\begin{array}{l}\text { Additive } \\
\text { effects }\end{array}$ & & {$[88]$} \\
\hline ZNF385D & $\begin{array}{l}\text { Zinc Finger Protein } \\
\text { 385D }\end{array}$ & $3 p 24.3$ & DLD & GWAS & & & [128] \\
\hline
\end{tabular}

DT: dysarthria; CAS: childhood apraxia of speech; ST: stuttering; SSD: other speech sound disorders; AP: aphasia; DLD: developmental language disorder; DL: dyslexia; ASD: autism spectrum disorder; CG: candidate gene; TM: targeted mapping; GWAS: genome-wide association study; GWLA: genome-wide link association; WES: whole exome sequencing; WGS: whole genome sequencing

the main target of the antibodies (Abs). Other Abs may also modify the clinical expression of the disease, such as Abs against muscle-specific tyrosine kinase $(\mathrm{MusK})^{[14]}$. A low percentage of genetic cases relate to other immune disorders ${ }^{[15]}$. Twin studies have shown that the concordance of MG is significantly higher in monozygotic compared to dizygotic twins. Several HLAs have been identified (HLA-A1,B8,DR3 haplotype for myasthenia gravis of early-onset and $H L A-A 3, B 7, D R 2$ and $H L A-D R 4$ for late-onset), as well as other nonHLA genes, as functional polymorphisms in the promoter of IL-10, haplotypes with TPN22, CTLA-4, TNIP1 and FOXP ${ }^{[14,16]}$. MuSK Ab-positive patients may associate with HLA-DR14 and DQ5 ${ }^{[14]}$.

Prominent bulbar symptoms with dysarthria are common in patients with ab-MusK. MusK is necessary for neuromuscular synapses to organize post-synaptic differentiation, including the clustering of receptors for the acetylcholine neurotransmitter. Anti-MusK autoantibodies are found in those seronegative patients. Although losing acetylcholine receptor function produces an autoimmune alteration, phenotypic particularities differentiate it from the classic MG. Thus, patients have a lower prevalence of ocular manifestations and greater weakness of neck and oropharynx. It tends to affect women and AfricanAmericans to a greater degree ${ }^{[14,17]}$.

Other relevant conditions with flaccid dysarthria: Because amyotrophic lateral sclerosis (ALS) affects both upper and lower motor neurons, the resulting dysarthria is mixed, (flaccid/spastic type). The initial symptoms include an alteration in the pattern and rhythm of speech, until it evolves into an unintelligible voice. As ALS progresses and dysarthria becomes severe, deep weakness resulting in reduced movement of the speech musculature and a severe reduction in phonation become increasingly common. However, an 
Table 2. Genes associated with dysarthria in different medical conditions

\begin{tabular}{|c|c|c|c|c|c|}
\hline Disease & Ref. & Type & Gene & Name & Locus \\
\hline \multirow{6}{*}{$\begin{array}{l}\text { Myasthenia } \\
\text { Gravis }\end{array}$} & \multirow[t]{6}{*}[13-17]{} & \multirow[t]{6}{*}{ Flaccid } & $/ L-10$ & Interleukin 10 & $1 q 32.1$ \\
\hline & & & PTPN22 & Protein tyrosine phosphatase non receptor type 22 & $1 \mathrm{p} 13.2$ \\
\hline & & & CTLA4 & Cytotoxic T-Lymphocyte Associated Protein 4 & $2 q 33.2$ \\
\hline & & & TNIP1 & TNFAIP3-interacting protein 1 & $5 q 33.1$ \\
\hline & & & FOXP3 & Forkhead Box P1 & Xp11.23 \\
\hline & & & \multicolumn{3}{|c|}{$\begin{array}{l}\text { HLA: HLA-A3,B7,DR2 (early-onset); HLA-A1,B8,DR3; HLA-DR4 (late-onset); HLA-DR14: HLA- } \\
\text { DQ5 (anti-MusK) }\end{array}$} \\
\hline \multirow{2}{*}{$\begin{array}{l}\text { Prader Willi } \\
\text { syndrome }\end{array}$} & \multirow[t]{2}{*}[13,19]{} & \multirow[t]{2}{*}{ Flaccid } & NDN & Necdin & $15 q 11.2$ \\
\hline & & & SNRPN & Small nuclear ribonucleoprotein polypeptide $\mathrm{N}$ & $15 q 11.2$ \\
\hline \multirow{4}{*}{$\begin{array}{l}\text { Amyotrophic } \\
\text { Lateral } \\
\text { Sclerosis }\end{array}$} & \multirow[t]{4}{*}[13,18]{} & \multirow{4}{*}{$\begin{array}{l}\text { Spastic/ } \\
\text { Flaccid }\end{array}$} & DCTN1 & Dynactin 1 & 2p13.1 \\
\hline & & & PRPH & Peripherin & $12 \mathrm{q} 13.2$ \\
\hline & & & SOD1 & Superoxide dismutase 1 & $21 q 22.11$ \\
\hline & & & NEFH & Neurofilament protein heavy polypeptide & $22 q 12.2$ \\
\hline \multirow{10}{*}{$\begin{array}{l}\text { Hereditary Spastic } \\
\text { Paraplegia }\end{array}$} & \multirow[t]{10}{*}[26]{} & \multirow[t]{10}{*}{ Spastic } & PGN & Paraplegin & $16 q 24.3$ \\
\hline & & & SPG11 & Spastic paraplegia 11 & $15 q 21.1$ \\
\hline & & & ZFYVE26 & Zinc finger FYVE domain-containing protein 26 & $14 q 24.1$ \\
\hline & & & SPG24 & Spastic paraplegia 24 & $13 q 14$ \\
\hline & & & SPG26 & Spastic paraplegia 26 & $12 q 13.3$ \\
\hline & & & SPG27 & Spastic paraplegia 27 & 10q22.1-q24.1 \\
\hline & & & SLC16A2 & Solute carrier family 16 member 2 & Xq13.2 \\
\hline & & & $D D H D 2$ & DDHD domain containing protein 2 & 8p11.23 \\
\hline & & & GJC2 & Gap junction protein gamma 2 & $1 q 42.13$ \\
\hline & & & C19orf12 & Chromosome 19 open reading frame 12 & $19 q 12$ \\
\hline Friedreich ataxia & {$[20,25]$} & Ataxic & $F X N$ & Frataxin & $9 q 21.11$ \\
\hline \multirow{14}{*}{$\begin{array}{l}\text { Spinocerebelar } \\
\text { ataxia }\end{array}$} & \multirow[t]{14}{*}[20,22-24]{} & \multirow[t]{14}{*}{ Ataxic } & ATAXIN1 & Ataxin 1 & $6 p 22.3$ \\
\hline & & & ATAXIN2 & Ataxin 2 & $12 q 24.12$ \\
\hline & & & ATAXIN3 & Ataxin 3 & $14 q 32.12$ \\
\hline & & & SPTBN2 & Spectrin beta nonerythrocytic 2 & $11 q 13.2$ \\
\hline & & & CACNA1A & Calcium-channel voltage-dependent P/Q type alpha $1 \mathrm{~A}$ subunit & 19p13.42 \\
\hline & & & ATXN7 & Ataxin 7 & $15 q 15.2$ \\
\hline & & & PRKCG & Protein kinase $\mathrm{C}$, gamma & $19 q 13.42$ \\
\hline & & & TTBK2 & Tau tubulin kinase 2 & $15 q 15.2$ \\
\hline & & & SETX & Senataxin & $9 q 34.13$ \\
\hline & & & SPTBN2 & Spectrin beta nonerythrocitic 2 & 11q13.2 \\
\hline & & & SACS & Sacsin & $13 q 12.12$ \\
\hline & & & MRE11 & Meiotic Recombination 11-Like Protein A & $11 q 21$ \\
\hline & & & KCNC3 & $\begin{array}{l}\text { Potassium channel voltage-gated shaw-related subfamily } \\
\text { member } 3\end{array}$ & $19 q 13.33$ \\
\hline & & & $D A R S 2$ & Aspartyl-tRNA synthetase 2 & 1q25.1 \\
\hline \multirow{13}{*}{$\begin{array}{l}\text { Multiple } \\
\text { Sclerosis }\end{array}$} & \multirow[t]{13}{*}[27,30-35]{} & \multirow{13}{*}{$\begin{array}{l}\text { Spastic/ } \\
\text { Ataxic }\end{array}$} & MS2 & Multiple sclerosis, susceptibility to 2 & 10p15.1 \\
\hline & & & MS3 & Multiple sclerosis, susceptibility to 3 & $5 p 13.2$ \\
\hline & & & MS4 & Multiple sclerosis, susceptibility to 4 & $1 p 36$ \\
\hline & & & MS5 & Multiple sclerosis, susceptibility to 5 & 12p13.31 \\
\hline & & & ITGA4 & Integrin alpha 4 & 2q31.3 \\
\hline & & & SPP1 & Secreted phosphoprotein 1 & $4 q 22.1$ \\
\hline & & & PSMC4 & Protease 26 s subunit ATPase 4 & $19 q 13.2$ \\
\hline & & & NLRP5 & NLR family pyrin domain containing 5 & $19 q 13.43$ \\
\hline & & & CACNATH & Calcium-channel voltage-dependent t type alpha $1 \mathrm{~h}$ subunit & $16 p 13.3$ \\
\hline & & & PD1 & Programmed cell death 1 & $2 \mathrm{q} 37.3$ \\
\hline & & & EIF2AK1 & Eukaryotic translation initiation factor 2 alpha kinase 1 & $7 p 22.1$ \\
\hline & & & MCIR & Melanocortin receptor & $16 q 24.3$ \\
\hline & & & HLA: HLA- - & HLA-DRB1, HLA-DQB1, HLA-DRA & \\
\hline Parkinson's Disease & {$[11,37-43]$} & Hypok & $S N C A$ & Synuclein alfa & $4 q 22.1$ \\
\hline & & & PINK1 & Pitein-induced putative kinase 1 & $1 \mathrm{p} 36.12$ \\
\hline & & & $\angle R R K 2$ & Leucine-rich repeat kinase 2 & $12 q 12$ \\
\hline & & & PARK2 & Parkin & $6 p 26$ \\
\hline
\end{tabular}




\begin{tabular}{|c|c|c|c|c|c|}
\hline \multirow[t]{9}{*}{ Laryngeal Dystonia } & {$[44,48]$} & Hyperk & TORTA & Torsin $1 \mathrm{~A}$ & $9 \mathrm{q} 34$ \\
\hline & & & $H P C A$ & Hippocalcin & $1 p 35$ \\
\hline & & & TUBBA & Tubulin beta $4 \mathrm{~A}$ & $19 p 13$ \\
\hline & & & THAP1 & Thao domain-containing protein 1 & $8 p 11$ \\
\hline & & & DYT7 & Dystonia 7 & $18 p$ \\
\hline & & & DYT13 & Dystonia 13 & $1 p 36$ \\
\hline & & & $\mathrm{ClZ1}$ & CDKN1A-interacting zinc finger protein 1 & $9 q 34$ \\
\hline & & & ANO3 & Anoctamin 3 & $11 \mathrm{p} 14$ \\
\hline & & & GNAL & $\begin{array}{l}\text { Guanine nucleotide-binding protein, alpha activity polypeptide, } \\
\text { olfactory type }\end{array}$ & 18p11 \\
\hline \multirow[t]{3}{*}{ Tourette Syndrome } & [59-61] & Hyperk & IMMPZL & Inner mitocondrial membranepeptidase subunit 2 & $7 q 31.1$ \\
\hline & & & $P N K D$ & Myofibrillogenesis regulator 1 & $2 q 35$ \\
\hline & & & CNTNAP2 & Contactin Associated Protein 2 & $7 q 35-q 36$ \\
\hline \multirow[t]{2}{*}{ Huntington Disease } & {$[62-64]$} & Hyperk & HTT & Huntingtin & $9 p 16.3$ \\
\hline & & & FOXP1 & Forkhead box 1 & $3 p 13$ \\
\hline \multirow[t]{5}{*}{ Essential Tremor } & [67] & Hyperk & DRD3 & Dopamine receptor D3 & $3 q 13.31$ \\
\hline & & & FUS & Fused in sarcoma & $16 p 11-2$ \\
\hline & & & TENM4 & Teneurin transmembrane protein 4 & $11 q 14.4$ \\
\hline & & & ETM2 & Essential tremor 2 hereditary & $22 p 5-p 22$ \\
\hline & & & ETM3 & Essential tremor 3 hereditary & $6 p 23$ \\
\hline
\end{tabular}

Hyperk: hyperkinetic; Hypok: hypokinetic

early speech therapy intervention improves the patient's ability to communicate ${ }^{[18]}$. Concerning Prader Willi syndrome, anatomical alterations in the mouth and larynx, and the underlying brain dysfunction, contribute to alterations in speech and language. Oral motor function, tone level and resonance are altered, with a characteristic flaccid pattern ${ }^{[19]}$. A summary of the main genes involved in both conditions are included in Table 2.

\section{Ataxic dysarthria}

Ataxic dysarthria relates to disorders that alter the cerebellar pathway. It is characterized by interruptions in the articulation of speech, irregularity in the intensity of the tone and marked vocal tension ${ }^{[12]}$. This group includes hereditary ataxia. So far, reports have identified over 30 genotypes. Hereditary ataxia may be progressive, such as spinocerebellar ataxia (SCA) and Friedreich's ataxia (FRDA), or sporadic, such as episodic ataxia (EA). SPAX also refers to those ataxias that often have a prominent component of spasticity, thus changing the patient's dysarthric characteristics ${ }^{[20]}$.

Trinucleotide expansion diseases relate to some hereditary ataxias, with mutations where repetitions of trinucleotides in certain genes or introns exceed the normal stable threshold that differs by gene, by unstable microsatellites that occur throughout all genomic sequences. This is the case of SCA1-7 and SCA17, where the repeated codon is CAG, which is the coding region for glutamine $(\mathrm{Q})$, resulting in a polyglutamine (polyQ) tract. FRDA, SCA8, and SCA12 are other examples, but they do not code for glutamine and categorize as non-PolyQ diseases ${ }^{[21]}$.

For those patients in whom the genetic screening tests for $S C A 1,2,3,6,7$, and $F R D A$ are negative (The most frequent ataxias), the study of small pathogenic intragenic variants for PRKCG, TTBK2, SETX, SPTBN2, SACS, MRE11, KCNC3 and DARS2 might be useful, as these are more prevalent secondary groups. It is especially helpful in patients with progressive onset disorders in childhood or adolescence and/or with a family history ${ }^{[20]}$. Several studies assessed the phenotypic particularities of disorders that generate ataxic dysarthria $^{[22-24]}$. Clinical characterization of the voice helps to discriminate between different types of ataxia and guides vocal therapy ${ }^{[24]}$.

Friedreich ataxia (FRDA): Friedreich ataxia (FRDA gene, locus 9q21.11) is the most common progressive hereditary ataxia, with an autosomal recessive inheritance pattern. It produces degeneration, among other structures, of white matter cerebellar areas and afferent pathways of different brainstem nuclei. Speech 
disturbances are usually less severe than in spinocerebellar ataxia and are almost exclusively due to cerebellar degeneration. No relationship between the severity of dysarthria and body ataxia exists. Some characteristic features of speech show a difficulty in maintaining a constant tone, with vocal instability during the speech or a reduction in the maximum speed of syllable repetition ${ }^{[25]}$.

Spinocerebellar ataxia (SCA): $S C A 3$ is the most common autosomal dominant ataxia worldwide, followed by $S C A 1,2,6$ and 7. The phenotype of SCAs varies and can affect only the cerebellum or other brain structures. For example, SCA6 and SCA5 generate a pure cerebellar syndrome due to cortical ataxia, while $S C A 1$ and $S C A 3$ have a diffuse affectation ${ }^{[20]}$.

SCA1 (ATXN1 6p22.3) has a greater effect on voice dimensions. Rough and strangled voice are predictors of disease severity ${ }^{[23]}$.

SCA3 (ATXN3 locus 14q32.12 gene) affects specifically the regularity of diadochokinetic syllable repetitions (DSR) if compared to the rest of hereditary ataxias. Also, the characteristics of the non-verbal oral motor deteriorate significantly in SCA3. The more widespread process of the brain and brain stem degeneration in $S C A 3$ may compromise non-speech tasks, such as DSR to a greater degree than other ataxias ${ }^{[22]}$.

SCA5 (SPTBN2 locus 11q13.2 gene) usually generates less dysarthric involvement than the rest of spinocerebellar ataxias. Unlike SCA1, only the strangled voice is a prognostic factor in the disease severity ${ }^{[23]}$.

Articulatory speech disorders especially affect to patients with SCA6 (CACNA1A gene, locus 19p13.13). Speech parameter degradations (frequency and modulation) are worse at SCA6. The speech parameters in prosodic modulation are also particularly vulnerable. It is due to neurodegeneration in $S C A 6$, which is largely (though not only) confined to the cerebellum. In contrast to many other types of SCA, cerebellar degeneration largely implicates the cerebellar cortex ${ }^{[22,23]}$.

Regarding SCA7 (ATXN7 gene, locus 3p14.1), voice deterioration is unrelated to age at onset and the length of the cytosine-adenine-guanine triplet tract. Surprisingly, the results of the acoustic analysis (jitter and shimmer) correlate with Inventory of Non-Ataxia Symptoms, but not with Scale for the Evaluation and Rating of Ataxia scores, which implies that voice deterioration results from extra-cerebellar clinical manifestations ${ }^{[24]}$. No other relevant studies that specifically assess the characteristics of dysarthria in other ataxic variants have been reported.

\section{Spastic dysarthria}

Spastic dysarthria is related to alterations in the upper motor neuron system. Unilateral involvement of the upper motor neuron is usually classified as a separate type. Patients have slow-moving speech, a tense voice and multiple breaks in pitch $^{[11]}$. Examples of spastic dysarthria are hereditary spastic paraplegias ${ }^{[26]}$ and other mixed expression disorders such as multiple sclerosis ${ }^{[27]}$.

Multiple sclerosis $(M S)$ : Multiple sclerosis is a demyelinating condition of unknown etiology in which environmental and genetic factors are involved. It generates a spastic, ataxic or more frequently mixed (spasticataxic) dysarthria. Studies of dysarthria in $M S$ show a prevalence ranging from $41 \%$ to $51 \%$. The main speech disturbances are in volume control, rough voice quality and imprecise articulation ${ }^{[27]}$. It may show cognitive deficits such as slowed information processing speed, impaired working memory and reduced information processing efficiency. It can also manifest as a subtle, non-phasic high-level language deficits ${ }^{[28]}$. Assessment of dysarthria may be helpful in controlling clinical and progression of a subclinical disease ${ }^{[29]}$.

A genetic susceptibility to the development of multiple sclerosis may exist, associated with certain $H L A$ genes, including $H L A-A, H L A-D R B 1, H L A-D Q B 1, H L A-D Q B 1, H L A-D R A$, on chromosome 6p21.3. Other haplotypes identified are $H L A-D R B 1^{*} 1501-D Q B 1^{*} 0602$ (HLA-DR15). Additional MS susceptibility loci 
include MS2 on chromosome 10p15, MS3 on chromosome 5p13, MS4 on chromosome 1p36 and MS5, influenced by the variation in the TNFRSF1A gene on chromosome $12 \mathrm{p}^{3} 3^{[30]}$. Several genes can modify the evolution of the disease. $F N 1$ and $C D 24 v / v$ are associated with an early-onset $M S^{[31-33]}$. Besides this, ITGA4, SPP1, SPP1, PSMG4, and NLRP5 relate to the disease severity, with SNPs having an allelic dosing effect ${ }^{[31,34]}$. PSMG4 encodes a chaperone protein implicated in the assembly of the $26 S$ proteasome (a primary protein deletion pathway). The reduced activity of proteasome $26 \mathrm{~S}$ has proved to cause neuronal death from abnormal protein degradation. Proteasome $26 S$ hydrolyzes the basic myelin protein to produce antigenic peptides for presentation to T-cells ${ }^{[30]}$. CACNA1H takes part in relapsing-remitting $M S$ at clinical onset. Polymorphisms in PD-1, NLRP5 and EIF2AK1 associate with disease progression ${ }^{[34,35]}$. MC1R relates to lateonset clinical symptoms ${ }^{[34]}$. Its protein encodes the melanocyte stimulating hormone receptor, and the identified variant associates with the phenotype of rutilism ${ }^{[31]}$.

\section{Hypokinetic dysarthria}

Alterations in the circuit that controls the basal ganglia (substantia nigra) cause hypokinetic dysarthria. The patients who suffer this disease speak in a monotone voice, with a reduction in tonal volume, a tendency to a speed up speech, inappropriate silences and palilalia. Patients show unexpressive facies, rigidity and body tremor. Parkinson's disease $(P D)$ and other degenerative parkinsonims represent this disorder ${ }^{[11]}$.

Parkinson's disease: A relevant gene in Parkinson's disease is SCNA, which encodes $\alpha$-synuclein $(a S y n)^{[36]}$. This protein plays a role in the brain, maintaining a supply of synaptic vesicles in the presynaptic terminals by grouping synaptic vesicles ${ }^{[37]}$. Transgenic mice that over-express human wild-type aSyn under a broad neuronal promoter (Thy1-aSyn) present initial motor and non-progressive motor deficits, followed by parkinsonism with dopamine loss. These motor deficits include early and progressive vocalization disorders ${ }^{[38,39]}$. PINK1 is a gene involved on early-onset $P D$. Pink1-KO rats have mitochondrial abnormalities, and proteinase K-resistant $a S y n$ aggregates in different brain regions ${ }^{[40,41]}$. Additionally, rats exhibit significant vocalization deficits dependent on age, intensity, bandwidth, and peak frequency ${ }^{[39]}$.

Speech disturbances may be early markers for $P D$ detection. A preliminary study of cognitive disorders in the Chinese Han population revealed an absence of significant differences in neuropsychological tests in language fluency between carriers of a known PD mutation (LRRK2 S1647T) and noncarriers ${ }^{[42]}$. However, a later report with more specific language criteria in Argentinian patients with asymptomatic mutations (PARK2 and LRRK2) who performed executive, semantic, verb construction, and syntactic tasks, showed alterations in a syntactic test with a minimal amount of working memory. These results suggest that these mutations may play a role in language processing ${ }^{[43]}$.

\section{Hyperkinetic dysarthria}

Hyperkinetic dysarthria relates to alterations in the basal ganglia pathway (caudate/putamen nucleus). It generates tense speech, swaying voice volume, suddenly forced breathing and multiple voice interruptions ${ }^{[11]}$.

Laryngeal dystonia $(L D)$ : Laryngeal dystonia is a form of focal dystonia characterized by intermittent spasms in the vocal folds that selectively affect speech production. Its etiology is multifactorial and polygenic. Metabolic, neurodegenerative, and environmental factors such as exposure to viruses or voice abuse can induce $L D$ in genetically predisposed patients ${ }^{[44]}$. Dopaminergic, GABAergic, glutamatergic and cholinergic neurotransmission is required in the pathogenesis of dystonia ${ }^{[45]}$.

$L D$ shows different clinical forms. In the most common adductor form, over-adduction of the vocal folds leads to voice interruptions in the vowels and the quality of the tense voice. The abductive form is rarer, with voice breakdowns in the consonants and whispered voice ${ }^{[46]}$.

Although the genotype and phenotype characteristics of $L D$ are different, functional connectivity alterations in the sensory-motor and frontoparietal cortex correlates with polygenic risk and may represent 
an intermediate endophenotype and primary marker of $L D$. Meanwhile, the genes involved in synaptic transmission and the development of neurons may be related to the molecular pathogenesis of this disorder. Patients with $L D$ have abnormal functional connectivity that affects speech production and auditory-motor integration as phenotypic characteristics. Structures initially described were the internal capsule and the cerebellum, as well as the thalamus, the corticobulbar tract and the basal ganglia ${ }^{[47]}$. Other imaging studies have reported alterations at left dorsal primary sensorimotor cortex, especially in the abductor forms. It also affects the frontoparietal cortex, at the angular gyrus, and shows a significant relationship with the age at onset ${ }^{[48,49]}$. Abnormalities in these regions correlate with underlying alterations in grey matter volume, cortical thickness and white matter downstream pathways as well as the genetic relationship with the functional connectivity of the premotor/primary sensory-motor and frontoparietal cortex ${ }^{[49]}$.

$L D$ genotypes are associated with structural changes in the extra Sylvian superior order regions and their pathways, suggesting a role for the temporal lobe in the pathogenesis of $L D$. Genotypic alterations are present in sporadic cases $v s$. familiar $L D$ in the supplementary motor area (SMA) and superior temporal gyrus $(S T G)$, as well as in the superior longitudinal fasciculus. Computerized tomography $(C T)$ differences in $S M A$ may reflect different processing from the motor functions closest to those performed by the primary motor cortex. Other specific genotypic alterations in $L D$ were located at the anterior portion of STG, where functional identification has shown greater activation in association with vocal auditory stimuli compared to non-voice sounds. Also, these abnormalities in STG may particularly affect individuals without a familiar background of dystonia ${ }^{[46]}$.

Up to $12 \%$ of patients with $L D$ report a familiar background. Genetic mutations suggest a weak predisposition that contributes to mechanisms that cause a non-progressive abnormality in the control of the laryngeal motor neuron for speech but not for vocal emotional expression ${ }^{[50]}$. More than 20 different types of dystonia, called DYT, can be distinguished genetically. Some of these associate with other neurological signs ${ }^{[48]}$. Some causative genes are highly expressed during early brain development ${ }^{[45]}$. The most common cause of primary generalized dystonia in childhood is DYT1 dystonia, caused by a 3 bp deletion $(\triangle G A G)$ in the TOR1A gene that encodes the Torsin A protein. Symptoms usually occur before the age of 21 with sustained involuntary muscle contractions caused by the position of a foot, leg or arm, with laryngeal involvement in some cases ${ }^{[51]}$. Genetic variation captured by the polygenic risk score and encompassing genes related to these biological processes may be directly relevant to the pathogenesis causing $L D^{[52]}$.

DYT6 dystonia typically affects the cranial muscles and arms, with voice involvement as the predominant characteristic. The causative gene is a protein associated with apoptosomes that contain the protein domain correlated with Thanatos 1 (THAP1), which encodes a DNA-binding protein. THAP1 can generate both generalized and isolated cases of dystonia. Identification of this mutation only appears in a few patients, usually middle-aged women ${ }^{[53]}$.

Polymorphisms may also be implicated in the higher or lower risk for developing $L D$. In the DYT1 gene, polymorphisms have been identified as associated with adult-onset primarily focal dystonias, including $L D$, and may increase or decrease the risk for developing dystonia ${ }^{[51]}$. In cases of non-familiar dystonia in the Icelandic population, a significant association was observed between dystonia and some markers comprising the DYT1 gene ${ }^{[54]}$. However, further results did not replicate the association ${ }^{[55]}$. Also, a study conducted by Sharma et al. ${ }^{[56]}$ on a large cohort of focal and segmental dystonia, including $L D$ and cervical dystonia patients, revealed a significant association between SNP rs3842225 and protection from the development of focal or segmental dystonia.

A functional magnetic resonance image ( $f M R I$ ) study compared a single carrier of GNAL mutations with a larger group of isolated $L D$ cases without known mutations. GNAL encodes the G-protein stimulating 
subunit $\alpha$, Golf, required in the dopaminergic, adenosine and corticotropin signaling pathways. The effects of striatal dopaminergic abnormalities may be reflected in aberrant frontoparietal cortical activity, leading to further alterations in the integrative preparatory and sensory-motor stages of GNAL mutation carriers compared to other $L D$ patients ${ }^{[50]}$.

TUBB4 is mostly expressed in brain development during the fetal period. The main regions of expression are the amygdala, hypothalamus, thalamus and prefrontal cortex. TUBB4 mutations implicate abnormal microtubule function, generating whispered voice DYT4 dystonia and other phenotypes of $L D^{[57]}$.

Some reports of isolated cases exist, such as the one proposed by Peng et al ${ }^{[58]}$ that described a patient with myoclonus, affecting the hands and arms, harboring the most common mutation in mitochondrial DNA causing myoclonic epilepsy with ragged red fibers syndrome (MERRF) [A-> G substitution in the 8344 nucleotide $t R N A$ ( $L y s)$ gene] that correlated with $L D$. Other genes involved in dystonia affecting laryngeal function are summarized in Table $2^{[48]}$.

Tourette syndrome: The internal mitochondrial membrane protein $2 \mathrm{~L}(I M M P 2 L)$ gene (7q22-q31) is an interesting candidate for Tourette syndrome (TS). IMMP2L encodes subunit 2 of the internal membrane peptidase, a mitochondrial protease involved in cleaving the space-sorting signals of mitochondrial membrane proteins. Defective $I M M P_{2} L$ can lead to altered mitochondrial function. The breakpoint in chr7 was assigned to 7q22-q31, between D7S515 and D7S552. This gene is also involved in autism and $S L D^{[59]}$. Interestingly, a familial balanced reciprocal translocation $\mathrm{t}(7 ; 15)(\mathrm{q} 35 ; \mathrm{q} 26.1)$ has been identified in one patient, interrupting the CNTNAP2 gene in phenotypically normal individuals ${ }^{[60]}$.

The PNKD gene, widely expressed in the brain, regulates myofibrillogenesis and has been associated with $T S$ and speech disorders. One report identified a G89R nonsense mutation in a child affected by intermittent ataxia, diarrhea, exercise intolerance, and speech articulation problems ${ }^{[61]}$.

Huntington's disease $(H D)$ : Huntington's disease is an inherited neurodegenerative disorder that causes motor, cognitive and neuropsychiatric disorders. It follows a pattern of autosomal dominant inheritance, initiating symptoms in the middle-aged, although it may also appear earlier or later. An unstable expansion of a $C A G$ sequence within the Huntingtin gene (HTT) causes this disorder, located on chromosome 4 . The protein encoded by the HTT gene plays a role in the normal development of the brain and neurons. The expanded $C A G$ sequence leads to the production of an abnormal protein that causes brain cell dysfunction and ultimately neuronal cell death primarily in the basal ganglia, but also the thalamus and cerebral cortex $^{[62]}$.

FOXP1, one of the most studied genes involved in a range of speech and language disorders and will be described in more detail later, implicates transcriptional HD dysregulation, interacting with $m H t t$. The combined analysis of microarrays and ChIP-seq in a striatal cell line that over-expresses this transcription factor identified a set of target genes, including those associated with inflammatory and immunological disorders. According to in vitro results, viral transduction of Foxp1 mainly led to the suppression of genes related to the immune system in the adult striatum ${ }^{[63,64]}$.

Essential tremor: Essential laryngeal tremor has phenotypic characteristics of hyperkinetic dysarthria. It occurs in greater proportion in women from the seventh decade of life onwards, and there may be a family component ${ }^{[63]}$. It may associate with other parts of the body and, as with essential tremor, improves with alcohol intake ${ }^{[65,66]}$. Genes correlating systemic clinical symptoms with dysarthria include DRD3 (3q13.31), FUS (16p11), TENM4 (11q14), and two loci: 2p25-p22 and 6p23 ${ }^{[67]}$. 


\section{Stuttering}

Stuttering is a speech disorder in which the flow of speech is interrupted by involuntary repetitions and prolongations of sounds, syllables, words or phrases, as well as pauses or blockages in which the patient is not able to make sounds. Numerous mechanisms explain the genesis of stuttering, with a strong genetic correlation. In this review we will only cite those genes that are present in non-syndromic stuttering. Around $9 \%$ of patients with a familiar background associates with the GNPTAB, GNPTG, and NAGPA genes $^{[68]}$. The importance of these genes is based on replication in subsequent studies, confirming a key role in stuttering ${ }^{[69]}$. These genes may also be affected in mucolipidosis. Unlike mucolipidosis, the characteristics of the mutations found in stuttering lie in their typically heterozygous character, with nonsense mutations, a modest reduction of enzyme function and different mutation sites ${ }^{[6]}$.

GNPTAB catalyzes the addition of mannose 6-phosphate label to hydrolytic enzymes, allowing lysosomal configuration. The gene is located at locus $12 \mathrm{q} 23.3$ and encodes the enzyme $\mathrm{N}$-acetylglucosamine-1phosphotransferase. It was the first gene implicated in stuttering, with non-sense mutations in several families regarding inbreeding ${ }^{[70]}$.

Through a systemic sequence of candidate genes, the GNPTG and NAGPA genes at 16p13 were identified in isolated stuttering cases. Variants of two genes were almost exclusively non-sense amino acid substitutions. GNPTG catalyzes the initial step in the synthesis of the mannose 6-phosphate $(M 6 P)$ required for efficient intracellular targeting of newly synthesized lysosomal hydrolases. It encodes a protein subunit that combines with the product of the GNPTAB gene to form the functional phosphotransferase enzyme. NAGPA catalyzes the second step in hydrolytic enzyme labeling for lysosomal orientation. It encodes the $N$-acetyl glucosamine-1-phosphodiester alpha- $N$-acetylglucosaminidase enzyme. These two enzymes comprise a simple two-step biochemical pathway, which serves to bind a remainder of mannose 6-phosphate that acts as a signal to a diverse group of hydrolytic enzymes in lysosomes ${ }^{[68]}$.

Another interesting gene is $A P 4 E 1$, which encodes the adaptive protein complex 4, subunit epsilon 1. A study in one Cameroonian family identified two cis mutations in the same haplotype [p.Val517Ile (c.G1549A) and p.Glu801Lys (c.G2401A)]. The stuttering cases had many predicted loss of function variants in AP4E1, including deletions, frame changes, nonsense, and splice site variants, while only nonsense substitutions were observed in the controls. All the mutations in cases and controls were present in a single copy ${ }^{[68]}$.

Other authors described association in additional chromosomal regions ${ }^{[71-73]}$. Using high density genotyping, $S L C 6 A 3$ and DRD2 were identified as other candidate genes in the Chinese Han population ${ }^{[74]}$. FOXP2 and CNTNAP2 variants do not seem to be involved in the genetics of familial persistent $S T^{[75]}$, although the reports of some authors question this categorical assertion ${ }^{[7,76]}$.

\section{Childhood apraxia of speech}

Childhood apraxia of speech (CAS) is a neurological speech disorder that affects the accuracy and consistency of the movements underlying speech. It may occur as a result of a known neurological impairment, in association with complex neurobehavioral disorders of known or unknown origin, or as an idiopathic neurogenic speech disorder ${ }^{[77]}$. Although in most cases its etiology is unknown, a genetic association has proven to be related to this disorder ${ }^{[5]}$. Authors define a synonymical for adults, verbal apraxia, albeit with particularities that differentiate it from $C A S^{[78]}$.

\section{FOXP2}

The FOXP2 gene (locus 7q31), part of the forkhead box family, was first described in the KE family (medical name designated for a British family), which showed speech articulation disorders, cognitive deficit and language delay ${ }^{[79]}$. It is the first ${ }^{[80]}$ and one of the most studied genes involved in speech and language 
disorders with a wide phenotypic expression ${ }^{[79,81]}$. FOXP2 acts as a repressor transcription factor that can form heterodimers with $F O X P{ }^{[81]}$. Its role in the development of speech and language is not entirely defined $^{[6,79]}$. A study identified 27 genes with differential regulation under human FOXP2 control. RT$q P C R$ and western blot studies showed the differential regulation of 13 additional target genes in response to human over-expression of FOXP2 ${ }^{[82]}$. The functional deficiency of FOXP2 affects both expressive and receptive language with a central characteristic of the abnormal articulation ${ }^{[7]}$. Its function at central nervous system has been proven by neuroimaging studies and animal models, participating in cell signaling and communication, metabolism, migration, differentiation, and expression regulation ${ }^{[82,83]}$.

Neuroimaging studies in humans have shown that mutations in FOXP2 show alterations in grey matter in various regions of the cerebral motor cortex associated with speech, such as the superior temporal and inferior frontal gyrus. FOXP2 is highly expressed in the dorsal striatum during human development. The mutation of this gene seriously alters this anatomical structure, altering the production and learning of speech. In the cerebellum, FOXP2 expression is mainly affected in Purkinje cells ${ }^{[1]}$. In addition, patients with intragenic FOXP2 deletions demonstrate a reduction in volume and activation in caudate nucleus, globus palidus, thalamus and hippocampus by repeating nonsense words ${ }^{[84]}$.

Regarding animal models, Foxp2 appears in medium spiny neurons of the mouse dorsal striatum. These neurons are required for the regulation of the glutamatergic signal in the cortex and the dopaminergic inputs in the midbrain, in addition to controlling motor behaviors. In Foxp2 heterozygous mice, synaptic corticostriatal plasticity decreases and extracellular dopamine levels increases in the striatum. They also exhibit cerebellar alterations ${ }^{[1]}$.

Clinically, the risk of developing SLD associated with FOXP2 among siblings depends on the genetic disorder. Thus, contiguous non-recurring genetic deletions ( $80 \%$ de novo mutations, $20 \%$ autosomal dominant inheritance), FOXP2 sequence variants (70\% de novo mutations, 30\% autosomal dominant inheritance) or maternal uniparental disomy 7 , with no increased risk for siblings are the acquisition patterns of FOXP2 mutations. Because large, non-recurring deletions that include FOXP2 and flanking DNA cause approximately $52 \%$ of the $S L D$ related to FOXP2, chromosomal microarray analysis is the first genetic test recommended. Other tests to consider are whole exome sequencing (WES), whole genome sequencing (WGS) and karyotype ${ }^{[85]}$. Some genetic alterations detected in this case are missense mutations and intragenic deletions ${ }^{[81]}$. In the karyotype screening, a balanced translocation or pericentromeric inversion involves 7q31.1 in almost $8 \%$ of FOXP2-plus and FOXP2-plus-related disorders alone ${ }^{[85]}$. Patients usually present mild cognitive impairment ${ }^{[81]}$.

\section{FOXP1}

Another relevant gene that participates in brain development with CAS background is FOXP1. The role of FOXP1 (locus 3p14) in the brain is not clear. However, some reports suggest that it may play a role in the diversification of motor neurons, through their interactions with Hox proteins, in neuronal migration, by activating Reelin signaling pathways, and in neuronal differentiation, through regulating Pitx 3 protein ${ }^{[81]}$. FOXP1 mutations relate to mental retardation with apraxia of speech and language alterations ${ }^{[86,87]}$. The phenotypic expression is variable. FOXP1, unlike FOXP2, contributes more significantly to global cognitive impairments that include the most severely affected expressive language ${ }^{[7]}$.

Foxp1 is one of several genes expressed in the mouse striatum. Deletions encompassing FOXP1 have been found in autistic patients with severe phenotype. Haploinsufficiency of FOXP1 may be directly implicated in the disorder by deregulation of FOXP2. Relevant Foxp1 haploinsufficiency produces altered vocal communication, deregulation of the Foxp2 target genes in the striatum and changes in excitability of the medium spiny neurons ${ }^{[1]}$. 
Other genes potentially associated with childhood apraxia of speech

There are multiple reports of diverse genes that in isolated form have been associated with CAS. We highlight, by the variety of genes described and their technique, some of them. Peter et al. ${ }^{[88]}$ identified two chromosome regions of interest (5p15.1-p14.1 and 17p13.1-q11.1) through copy number of variants (CNV) and complete exome sequencing in two multigenerational families. The primary gene of interest was CDH18, expressed primarily in the cerebellum. They described other genes with possible additive effects, such as MYO10, which has high levels of gene expression in the basal ganglia and thalamus; NIPBL, which is present in basal ganglia, the cerebellum and the corpus callosum; GLP2R, expressed in cortex and also implicated in other language disorders, such as autism; NCOR1, present in basal ganglia and cerebellar cortex; FLCN, present in dentate rotation and the cerebellar cortex and other genes with more dispersed expression, especially in the cerebellum, such as SMCR8, NEK8 and ANKRD12. ANKRD12 is located in a dyslexia candidate region, DYX6, at 18p11.22. Another gene of interest is C4orf21 (ZGRF1) at 4q25-q28.2. ZGFR1 encodes a protein with similar functions related to motor praxis, highly expressed in the cerebellum. A set of co-expressed regulatory genes in the human embryonic brain also relates to CAS. By analyzing whole genome sequences of nineteen subjects, de novo mutations in CHD3, SETD1A and WDR5 and loss of function mutations in SETBP1, KAT6A, TNRC6B, and ZFHX4 were characterized as pathogenic ${ }^{[89]}$. Other genes described were CNTNAP2 alone or associated with overlapping CAS phenotype disorders (ATP13A4, CNTNAP1, KIAA0319, and SETX $)^{[90]}$. Rare mutations in ELKS/ERC1 suppressions, a member of the RIMbinding protein family, have been reported ${ }^{[91]}$. Surprisingly, in this case the ANKRD12 gene, among others, were considered variants of uncertain significance ${ }^{[91]}$. Through array comparative genomic hybridization other candidate genes were identified in a multigenerational London pedigree, at locus 2p16, 5q22, 6p21, 13q21, 15q4, 16p13, 16q23.2, and $19^{[92]}$. Newbury et al ${ }^{[93]}$ described dual copy number variants involving $16 \mathrm{p} 11$ (a region of genes involved in speech disorders already described such as SETD1A and FUS) and 6q22 in a $C A S$ case-report with developmental disorder.

\section{Other speech sound disorders}

This section includes other speech disorders in which the patient has difficulties in the formation of phonemes that interfere with verbal communication. It can cause articulation, phonemic or mixed alterations ${ }^{[94]}$. These conditions can also alter the literacy process by concurring with other language disorders, such as dyslexia and developmental language disorder, to determine patients' literacy skills, and share genetic determinants ${ }^{[95]}$.

In other speech sound disorders (SSD), several chromosomal alterations have been identified (chromosomes $1,3,6,7,8$ and 15$)^{[7]}$. DCDC2 and KIAA0319 strongly correlate with phonological awareness, influencing language and cognitive traits ${ }^{[82,96]}$. Nopola-Hemmi et al ${ }^{[97]}$ analyzed a large Finnish family and found a link with DYX5 (3p12-q13). Others reported involvement of DYX8 (1p36-34), whose role is unknown. CYP19A1 (15q21.2), implicated in the synthesis of lipids and hormones, has been associated with SSD and dyslexia ${ }^{[9899]}$. Some reports correlate $D Y X_{1} C_{1}$ with $S S D$ phenotypes. A ROBO1 linkage has been found to other SSD. Additional candidate genes include ELP4, PAX6 and FOXP2 ${ }^{[100]}$.

\section{GENOMICS OF LANGUAGE DISORDERS}

\section{Aphasia}

Aphasia is an alteration in the understanding and/or production of language because of damage to specific brain regions. Stroke is the most common cause of aphasia with alterations normally limited to the injured area, although neurodegenerative diseases such as Alzheimer's disease $(A D)$ or primary progressive aphasia (PPA) may also associate with more diffuse lesions. In these conditions, the genes involved in the development of aphasia have been studied in a more in-depth perspective. In $A D$, cognitive impairment extends beyond language and typically involves episodic memory, while in PPA affects gradually language skills with acceptable retention of nonverbal skills and activities of daily living. The type of aphasia seen 
in $A D$ depends on the phase of the disorder. In the early stages, anomalous aphasia, occasional semantic substitutions, occur due to difficulty in finding the right words (paraphasia), but speech is preserved. Later on, these individuals exhibit transcortical sensory aphasia, in which the patient has a clear anomic aphasia, and comprehension is affected. During moderate and severe stages of $A D$, lost fluency, increased use of wrong words, incorrect pronunciation, and poor comprehension is found. Finally, advanced stages include echolalia and verbal stereotypes. Primary progressive aphasia, on the other hand, classifies as fluent or nonfluent. In the fluent variant, prosody is normal, well-articulated and grammatically correct, but progressively circumlocutory and lacking in content words. The alteration of language correlates with a degradation of semantic memory and, therefore, the fluent variant is often mentioned as semantic dementia. In the nonfluent variant, speech is strained and hesitant, with phonemic paraphernalia. In a study of patients with a pathologically proven $A D, P P A$ patients had a higher proportion of neurofibrillary tangles in languagerelated neocortical areas on the entorhinal cortex compared to patients with an amnesic presentation ${ }^{[101]}$.

\section{Apolipoprotein E}

Because of its relevance in Alzheimer's disease and cerebrovascular metabolism, Apolipoprotein E (APOE) needs to be highlighted for its role in aphasia ${ }^{[102,103]}$. A non-memory $A D$ phenotype appears in approximately $25 \%$ of patients with early-onset disease ${ }^{[104]}$. Compared to the memory phenotype, language $A D$ phenotype has different demographic characteristics, genetic profile, and course of disease. This subgroup has smaller odds to carry at least one APOE4 allele relative to the memory subgroup, especially at an early-onset ${ }^{[105]}$.

APOE4 is over-represented in $P P A$, so it is likely to act as a genetic risk factor in the development of the disease ${ }^{[106]}$. A study by Daniele et al. ${ }^{[107]}$ showed that women with the APOE genotype $\varepsilon 2 / \varepsilon 4$ showed an increased risk for $P P A$ compared to women with homozygosis $\varepsilon 2 / \varepsilon 2$ or $\varepsilon 4 / \varepsilon 4$, suspecting that the $\varepsilon 3$ allele might play a protective role in PPA and frontotemporal dementia (FTD). Interestingly, Seripa et al. ${ }^{[108]}$ showed an association in the chromosomal region 19q13-q13.2, which included in addition to APOE, the TOMM4O, and $A P O C 1$ genes.

\section{Presenilin-1 and GLI family zinc finger 3}

Presenilin-1 (PSEN1) plays an important role in $A D$. Cases of visual or apraxic and language phenotypes are more frequent, with reports of atypical presentation with speech alteration, in carriers with PSEN1 mutations. It encodes a protein that takes part in the $\gamma$-secretase complex involved in the production of betaamyloid. However, considering language performance certainly GLI family zinc finger 3 (GLI3) is more remarkable. A study that associated magnetic resonance image (MRI) and GWAS showed brain atrophy in semantic and language areas in GLI3 variants. This gene is one of the three GLI zinc finger transcription factors that are normally implicated in pattering brain structures as an important mediator downstream of the Sonic Hedgehog pathway. It may act as an activator or repressor in the presence or absence of Sonic Hedgehog. GLI3 is negatively regulated in the presence of PSEN1, which ultimately leads to decreased neuronal differentiation. Mutations in the PSEN1 gene are responsible of several autosomal dominant $A D$, including mutations with an aphasic phenotype ${ }^{[109]}$.

\section{Other genes potentially associated with aphasia}

In a study of patients with clinically diagnosed FTD spectrum syndromes, genetic variations within FOXP2 do not pose a genetic risk per se but modulate the presentation of FTD. A significant and specific association between $r s 1456031 \mathrm{TT}$ and $r$ s17137124 TT genotypes and verbal fluency scores occurs, with left frontal hypoperfusion $^{[106,110]}$.

Granulin $(G R N)$ is a gene that encodes progranulin and leads to a haploinsufficiency syndrome. In these families, affected individuals may show PPA phenotype, while others show the behavioral variant FTD phenotype $(b v F T D)$. A family study reported that inclusions containing the transactional response DNA- 
binding protein 43 (TDP-43) were distributed asymmetrically with a higher concentration in the left hemisphere language cortices ${ }^{[111]}$. A retrospective report suggested that the mutations in the three genes most commonly associated with FTD [GRN, open-reading chromosome 9-frame 72 (C9ORF72); the microtubuleassociated tau protein $(M A P T)]$ were not correlated with $P P A^{[112]}$. However, these results must be taken with caution as the resulting sample had an over-representation of $P P A$ with speech disease, which often predicts the pathology of $A D$.

Prion protein gene (PRNP) modulates PPA disease, leading to specific regional hypoperfusion according to different molecular pathways ${ }^{[106,111]}$. Methionine/valine polymorphism of codon 129 may be over-represented in this disease compared to controls, $b v F T D$, and motor neuron disease, with the possibility that codon 129 polymorphisms could influence the selective susceptibility to the language network to neurodegeneration, even when the condition is unrelated to prion disorders. However, subsequent studies have failed to replicate the results ${ }^{[111]}$.

\section{Developmental language disorder}

Developmental language disorder $(D L D)$ is a disorder diagnosed in childhood with a delay or disturbance in language development. An early sign is a delay in language acquisition, and then they take time to put words together to form sentences. Spoken language can be immature. In many children with $D L D$, receptive language is also affected ${ }^{[113]}$.

\section{CNTNAP2}

This gene has been highlighted previously in several speech disorders. However, its link to language deficits is also relevant. CNTNAP2 expression is regulated by the transcription factor $F O X P{ }^{[5]}$. It encodes a protein, neurexin, which plays its role in shaping potassium channels in developing neurons (nodes of Ranvier) and plays an important function in facilitating axonal-glial interactions and cell growth ${ }^{[114]}$. It locates on chromosome $7 \mathrm{q}$, and it shows a wide range of alterations in other neurological disorders, including neuropsychiatric conditions, such as schizophrenia, $A D H D$ or bipolar disorder. Homozygous mutations lead to CASPR2 deficiency disorder $(C D D)$, a rare and severe syndrome with epilepsy, language impairment and intellectual disability ${ }^{[115]}$. CNTNAP2 was the first gene to be associated with genetically complex forms of $D L D$ and involved in early language acquisition ${ }^{[116]}$. However, its association with $D L D$ needs replication, as the specific causal variants and underlying mechanisms by which it may contribute to language alteration have not been elucidated. CNTNAP2 deletions in children with apraxia of speech unrelated to DLD implies the great phenotypic heterogeneity of this gene ${ }^{[117]}$. However, a study conducted by Toma et al. ${ }^{[115]}$ that exhaustively examined the role of CNTNAP2 in susceptibility to psychiatric disorders demonstrated that the distribution of $C N V s$ from previous reports was no different from the controls in the genomic variant database. These gene-based association tests found no common variants in psychiatric phenotypes such as autism and schizophrenia. Cntnap2 alters neurons by increasing the number of active synaptic sites and facilitating network activity. In mice, Cntnap2 knockdown had the most pronounced effects in the hippocampus ${ }^{[11]}$. Initially, outbred KO Cntnap2 mice had no macroscopic anatomical or neurological abnormalities, but when these mice were crossed with the C57BL/6J strain, subsequent generations exhibited neurologic abnormalities. Their abnormalities are similar to patients with cortical dysplasia and focal epilepsy syndrome ${ }^{[118]}$. Cntnap2 expression in robust nucleus of the arcopallium $(R A)$ is important for the proper production of learned vocalizations in songbirds. In adult zebra finches, the Cntnap2 transcription is enriched in cortical nuclei in the song production system. Adult females have moderate transcription levels in $R A$ and the lateral magnocellular nucleus of the anterior neostriatum (LMAN), with a uniform Cntnap2 distribution throughout striatopallidum. Interestingly, in young females, Cntnap2 is enriched in $R A$ to the same degree as for males and decreases to the level of the surrounding $R A$ with age. The reduction in gene expression coincides with the sensorimotor period of song learning in male, a time when the songbird begins to practice singing. The percentage of cells that express the protein in female RA decreases at this time ${ }^{[119]}$. 


\section{C-maf inducing protein and ATPase Secretory Pathway $\mathrm{Ca}^{2+}$ Transporting 2}

These additional and closely related genes are likely to contribute to vocal learning ${ }^{[11]}$. Applying a positional fine-mapping approach, which required a GWAS study followed by targeted high-density association research, two genes were implicated in language capacity: the c-maf-inducing protein $(C M I P)$ and the calcium-importing ATPase, type $2 \mathrm{C}$, limb $2\left(\mathrm{ATP}_{2} \mathrm{C}_{2}\right)^{[120]}$. GWAS analysis in these families revealed a strong and consistent linkage to locus $16 \mathrm{q} 24$ with the non-word repetition test. In other tissues, CMIP is involved in a cascade of cell signaling, such as the T-cell pathway and in the binding of phospholipids. ATP2C2 hydrolyzes ATP and is part of a pathway responsible for transporting divalent ions to the Golgi apparatus, such as calcium ${ }^{[113]}$. Linkage analysis and subsequent directed association analyses have suggested that $C M I P$ and $A T P 2 C 2$ relate to language disorders (especially non-word repetition) and phenotypic measures well characterized in these disorders. Although both molecules express in the brain, their functions are still poorly understood. These genes implicate a significant association with short-term memory. Considering that a relationship between wordless repetition test performance and short-term memory exists, $A T P 2 C 2$ and CMIP can provide a biological link between memory-related pathways and language acquisition. The fact that neither $A T P 2 C 2$ nor $C M I P$ have been identified as downstream targets of FOXP2 suggests that the eventual combination of information from convergent research pathways will allow the characterization of overlapping and interacting neurological systems that serve for language acquisition. Although the linkage to these genes has documented in subsequent studies, their association with $D L D$ has not been replicated yet. $A T P_{2} C_{2}$ has also proved to be linked to attention deficit hyperactivity disorder $(A D H D)^{[121,115]}$.

\section{Other genes potentally associated with developmental language disorder}

FOXP1 and KIAA0319 genes appear to be involved in $D L D^{[122]}$. A haploinsufficiency in SETBP1 (locus 18q12) is a factor implicated in CAS, but also in language impairment, responsible for interacting with an oncogene implicated in $D N A$ replication ${ }^{[123,124]}$. Other genes potentially related to language skills are $A B C C 13^{[125]}, F L N C$, $\mathrm{RBFOX}_{2}{ }^{[126]}$, and $\mathrm{ROBO}{ }^{[127]}$. GWAS studies have highlighted risk variants in NDST4, ZNF385D, COL4A2 ${ }^{[128]}$, and $N O P 9^{[129]}$. Other studies involve rare genetic events that may have greater penetrance. Also, the coding variants within NFXL1 confer a higher risk for $D L D$ within a complex genetic mode ${ }^{[130]}$. A study conducted by Centanni et al. ${ }^{[117]}$ evaluated $15 q 11.2$ as a region of susceptibility for $S L D$, finding two deletions in seven patients with CAS but none in 8 SLI. The main limitation of this study was the small number of patients (8 subjects). In a report looking for rare copy number variants in 58 subjects and their relatives, deletions were found on chromosome $16 \mathrm{p} 11.2$ in $3.4 \%$ of the probands. Other detected deletions were identified in 18p11.32-p11.22 and Xp22.31-p22.33 loci. Although the proportion is low, it should be noted that this locus overlaps with other neurodevelopmental disorders ${ }^{[131]}$. Several other minor reports exist, such as a balanced $\mathrm{t}(10 ; 15)$ translocation in a male patient with developmental language disorder ${ }^{[132]}$. This last example, although interesting, is just a case-report, so results cannot prove causation and may not be generalizable.

\section{Dyslexia}

Dyslexia $(D L)$ is a complex term characterized as a reading disorder. Subjects usually have normal intelligence and features that differentiate it from language impairments in patients with mental retardation ${ }^{[133]}$. Problems can include difficulty in spelling or writing words, reading quickly, pronouncing words mentally or when reading aloud, and understanding what the individual is reading ${ }^{[134]}$. Some authors consider dyslexia as an associated condition of developmental language disorder ${ }^{[135]}$ or $A D H D^{[136,137]}$. As noted, the truth is that many patients exhibit alterations in speech and language. Silencing of some of the most important genes involved in rodents, such as DCDC2, KIAA0319 and DYX1C1, produces deficits in neuronal migration, dyslexia, and alterations in working memory, auditory processing and visual attention $^{[138]}$. Within the human genome, genetic mapping reports have identified regions of different chromosomes, known as DYX loci ${ }^{[139-143]}$ and other related genes.

\section{Dyslexia susceptibility 1 candidate gene 1}

In animal models, $\mathrm{PYX}_{1} \mathrm{C}_{1}$ (15q21) mutations generate a neuronal migration disorders that correlates with $D L$. $D Y X_{1} C_{1}$ knockdown in zebrafish results in alterations in the primary cilia, such as body curvature 
disorders, hydrocephalus, renal cysts, and organ inversion left-right asymmetry. Other animal models have revealed unexpected roles for $D Y X_{1} C_{1}$ in primary cilia which are typical phenotypes of ciliary defects with similar results in $K O$ mice $^{[138]}$. Taipale et al ${ }^{[144]}$ identified a missense mutation ( $\left.r 557809907,1249 G>T\right)$ in some families with $D L$. This mutation results in Glu417X with a truncated protein. Later reports found a correlation with the common $G$ allele. Interestingly, a report of $D L$ in Chinese children also found a strong association with the $G$ allele. A allele shows decreased binding to a repressive transcription factor. Lim et al. . $^{[15]}$ hypothesized $A$ allele is protective compared to $G$ allele. Two other SNPs, $r s 12899331$ and $r$ s16787, in the promoter region were found to be involved in the binding to the transcription factor, but they did not associate with $D L$ in subsequent studies. Its protein can bind to the estrogenic receptor, suggesting an involvement of hormonal pathways in dyslexia ${ }^{[146]}$.

\section{$D C D C 2$}

The gene structure is analogous to the $D C X$ gene linked to $\mathrm{X}$, involved in the microtubule structure and neural migration. Defective $D C D C 2$ causes delays in neural migration in the embryonic brain. The $D C X$ gene mutation causes lissencephaly in men and cortical abnormalities in women ${ }^{[14]}$. In vitro studies showed that sequences in the region act as enhancers of $D C D C 2$ expression. Differences in gene expression may have a measurable phenotypic effect on brain structure ${ }^{[82]}$. Homozygous $D c d c 2$ KO mice exhibit auditory processing and memory deficits, as well as electrophysiological changes in cortical neurons with normal brain development ${ }^{[148]}$.

Early findings showed that $D C D C 2$ would be a strong candidate for developmental dyslexia. However, some futher studies did not find its association. Sequence analysis of $D C D C 2$ coding regions in families with $D L$ has not identified causal mutations; the only correlation of $D L$ was reported with a deletion in intron 2 which appeared to contain the transcription factor binding sites ${ }^{[149]}$. This deletion was not found in a further study on a Hong Kong population ${ }^{[150]}$. However, it has identified also in a Chinese group of children that the T-G$C-T$ of the four-marker haplotypes (rs9295619-rs807701-rs807724-rs2274305) and the T-A of the two-marker haplotype ( $r$ s3765502-1087266) were significantly different between cases and controls ${ }^{[151]}$.

\section{KIAA0319}

Although the role of this gene is unclear, decreased expression in the rat's embryonic brain leads to delayed neural migration ${ }^{[7]}$. SNPS at $5^{\prime} U T R$, the first untranslated exon and the first intron, suggest regulatory functions. The first reports linking this gene to dyslexia were described by Francks et al ${ }^{[152]}$, identifying it as a 77-kilobase region of chromosome 6p22.2. Further mapping studies identified KIAA0319 as the susceptibility gene for dyslexia with risk effects indexed by the $r s 761100$ in intron $1^{[153,154]}$. The expression of the allele containing the SNP haplotype associated with dyslexia in this region of KIAA0319 decreases in cell lines of individuals with this pathology. Another SNP, $r s 9461045$, has proven to have a regulatory function. Reporter trials showed that the risk allele, which was believed to create a binding site for the OCT1 repressor, resulted in a decreased expression of KIAA0319. Regions of acetylated histones in and around the gene were mapped on a neuroblastoma cell line to identify promoting regions. SNPs within or close to the acetylated region have been correlated with language-disturbing phenotypes, and linkage to the $D C D C 2 /$ KIAA0319 region has been reported for $S S D^{[85]}$. KIAA0319/TTRAP/THEM2 polymorphisms influence the laterality of activation in the superior temporal sulcus. Thus, these genes seem to influence the activity of the two hemispheres asymmetrically in areas related to language function ${ }^{[155]}$.

Other genes potentially associated with dyslexia

According to animal models, Robor gene participates in axonal development across the midline of the central nervous system and spinal cord ${ }^{[156]}$. Partial haploinsufficiency may cause dyslexia in humans ${ }^{[157]}$.

MRPL19 and C2ORF3 are two genes in which their role as co-regulators in dyslexia has been theorized. The MRPL19 protein is a component of the mitochondrial ribosome, but the function of the $\mathrm{C}_{2} \mathrm{ORF} 3$ gene 
is unknown. In one study, transcripts of one allele from MRLP19 and C2ORF3 decreased in individuals carrying risk haplotypes in the adjacent region suggesting that a mutation unknown in the SNP association region might affect the expression of both genes ${ }^{[158]}$. TTRAP (6p22.3), required in magnesium ion binding and DNA binding and repair ${ }^{[99]}$, and $\mathrm{ROBO}_{2}$ (3p12.3) are other genes potentially involved in $D L . R O B O 2$ is implicated in the guidance of axon and tumor molecular signaling and necrosis factor ${ }^{[98,159]}$. Landi et al ${ }^{[160]}$ found a COMT Val/Met polymorphism (rs4680) associated with reading skills. Other relevant genes are CMIP, MC5R, DYM, NEDD $4 L$ and DGK1 $1^{[161,154]}$.

Other suggested associations reported by Eicher et al. ${ }^{[162]}$ were dopaminergic genes related to ANKK1 and $D R D 2$, and nicotinic genes related to CHRNA3 and BDNF with case-control status and articulation. DRD2 has demonstrated its role in vocabulary alterations and a direct association with dyslexia ${ }^{[163,164]}$. ASPM is another gene whose alterations involve dysfunctions in vocabulary and reading, and AVPR1A with them and phonological memory ${ }^{[163]}$. These results support previous reports involving dopaminergic and nicotinic neural signaling in human communication and cognitive development.

Several $C N V$ studies identified genes involved in dyslexia. Thus, the interruption of a gene involved in learning, cognition, and memory through dendritic spinal synaptic plasticity, the PCDH11X protocadherin gene (by duplication or elimination of the gene) located in Xp21.3, could be caused by unequal recombination between the X transposed region (XTR) of Yp11.2 and the X chromosome ${ }^{[165]}$. The same authors in a subsequent report with similar methods identified rearrangements at 17q21.31, with KIAA1267, LRRC37A, $A R L 17 A / B, N S F P 1$, and NSF as candidate genes. Some of these genes seem to play a role in membrane fusion and synaptic transmission ${ }^{[166]}$. A further study searching for another large group of genes including, among others, CHRNA7, Corf22, IMMP2L and CNTNAP2 found no substantial proportion of variance in $D L^{[167]}$.

\section{OTHER COMPLEX GENETIC DISORDERS WITH SPEECH AND LANGUAGE IMPAIRMENTS}

As observed in dysarthria, there are multiple disorders that can be associated with speech and language impairments. Several genetic syndromes such as Worster-Drought or Flotaing-Harbor are characterized by alterations in verbal communication ${ }^{[85]}$. In this section of the review we will focus on some of the most prevalent genetic syndromes.

\section{Autism-spectrum disorders}

The great clinical heterogeneity of $A S D$ implies variability in the phenotypic characteristics of language and speech. $A S D$ has comorbid phenogenotypes, such as $A D H D^{[168,169]}$. Therefore, there may be alterations in the comprehension, dyspraxia or motor alterations ${ }^{[170]}$. The inversion of the pronoun, echolalia and a delay in understanding the reduced or even inverted production are the most frequent language alterations ${ }^{[171]}$. Because of this complexity, this review will focus on the major known genes directly associated with oral comunication disorders.

The sushi domain protein SRPX2 is a FOXP2 target ${ }^{[172]}$. Historically, it has been primarily studied as a complement cascade regulator in the innate immune system. SRPX2 is involved in neural development and migration. It encodes a protein that regulates synapse formation and ultrasonic vocalization in mice. SRPX2 mutations in humans have been linked to $S L D$, such as apraxia of speech in cases with rolandic seizures. The Sprxz knockout mouse shows a decrease in VGlut2 synapse density in the IV layer of the somatosensory cortex, and a reduction of VGlut1, VGlut2 and VGAT synapse densities in the CA2 region of the hippocampus. Srpx2 KO mice show an abnormal ultrasonic vocalization ontogenetic profile ${ }^{[173]}$. Interestingly, Srpx2 KO mice show a reduced preference for social novelty, which may prove a relationship between SRPX2 and autism-related behaviors ${ }^{[174]}$. 
$M E D 13 L$ is implicated in neural crest induction and is highly expressed in the cerebellum after birth ${ }^{[175]}$. $M E D 13 L$ relates functionally to EP300 and CREBBP products, link proteins between the FOXP2 and ROBO1 pathway ${ }^{[176]}$. In a case-report described by Jimenez-Romero et al. ${ }^{[17]}$ a SNP was identified in MED13L (chr12: $116675396 \mathrm{~A}>\mathrm{G}, \mathrm{G}, \mathrm{GRCh} 37$ ), which associates with a profound language disturbance in the expressive domain, cognitive retardation, behavioral disturbances and an autism-like phenotype.

Regarding other genes potentially associated, locus 16p11.2, previously described in $D L D$, has previously demonstrated a relationship with $A S D^{[112]}$. Bartlett et al. ${ }^{[178]}$ identified two loci related to DLD and ASD (15q25.1 and 16p12.3). The two link signals showed specificity by alterations of oral language for 15q and by deterioration of written language for 16p. These results show a subset of individuals with reading problems that do not have a comorbid oral language deficit. Also, high FOXP1 expression may contribute to the pathogenesis of $A S D^{[85]}$. In a study conducted by Chien et al. ${ }^{[179]}$ showed a significant increase in FOXP1 $m R N A$ levels in patients with ASD compared to the control group. Other genes that involve SLD and autism have yielded conflicting results. The association of CNTNAP2 has been reported. In the Chinese Han population, susceptibility to autism showed that a common non-coding variant (rs10500171) was related to increased risk, and T-A (rs7794745- rs10500171) and A-T-A (rs10244837- rs7794745- rs10500171) haplotypes also showed evidence of association ${ }^{[180]}$. These variants are involved in several neurological functions; for instance $r 57794745$ has a relevant role in audio-visual speech perception, voice-specific brain function and it is associated with reduced grey matter volume in left superior occipital gyrus ${ }^{[115]}$. A Spanish case-control association study did not find those common variants of FOXP2 that contributed to the susceptibility of autism, which is consistent with previous reports ${ }^{[181,182]}$. Moreover, the association of two CNTNAP2 SNPs (rs2710102 and rs7794745) with autism was not replicated in futher studies, although their potential implications in brain connectivity ${ }^{[115,182]}$. Purkinje-cell Tsc1 mutant mice show behaviors relevant to ASD, including changes in vocalizations ${ }^{[183]}$. MET gene is selectively expressed in brain structures involved in higher levels of not only language skills, but also social, cognitive and executive functions ${ }^{[184,185]}$. Other reported genes that involves communication impairments and $A S D$ are $C T T N B P 2^{[186]}, E N 2^{[187]}, N B E A^{[188]}$, $H R A S^{[189]}$, and $P T E N^{[190]}$. Other genes involved in language skills contribute to communication traits in children with $A S D$. Eicher et al. ${ }^{[191]}$ examined the association of genes previously implicated in SLD in children with $A S D$, finding associations with $A T P 2 C_{2}$ and MRPL19 genes. Other genes suggestively associated were CMIP, GCFC2, KIAA0319L, the DYX2 locus and DRD2. It is also possible that somatic mutations affecting a subset of neurons may cause language deficits in $A S D^{[192,193]}$.

\section{Other syndromes that associate with speech and language disorders}

Patients with Down syndrome (trisomy 21) have a more altered expressive than receptive language ${ }^{[194]}$. Children tend to have altered syllable structure, group reduction, and final consonant elimination. Prevalence of stuttering is also higher ${ }^{[195]}$. As they grow up, language has shorter and less complex statements. In senescence, SLD overlap with the increased risk of dementia ${ }^{[194]}$.

Fragile X syndrome (FXS) is the main inherited cause of intellectual disability, accounting for $40 \%$ of all $\mathrm{X}$-linked mental retardation. The syndrome results from a mutation in the FMR1 gene, which locates on the $\mathrm{X}$ chromosome (Xq27.3). The mutation induces an expansion of $C G G$ triplet repetition within FMR1. FMR1 encodes fragile $\mathrm{X}$ mental retardation protein $(F M R P)^{[196]}$. In songbirds, FMRP expresses in the HVC, LMAN, $R A$, and area $X^{[11]}$. FMRP enriches in male $R A$ from the beginning of the sensorimotor learning phase. Autism is a common comorbid condition in people with FXS, modifying the phenotypic characteristics of the subject. A characteristic communicative alteration in FXS patients is a repetitive language. Other alterations implicate delay progress of vocabulary, comprehension, and syntax. FXS patients have significant weaknesses in pragmatics. Their ability to recognize and provide the necessary informative details in language discourse affects more than expected their levels of cognitive development ${ }^{[197]}$. 


\section{EPIGENETICS OF SPEECH AND LANGUAGE}

In songbirds, epigenetic modifications related to call are reported on early-expressed genes. These genes are associated with the activity of the cytoskeleton $(A r c)$ that interacts with endocytosis-related proteins and facilitates the removal of $\alpha$-amino-3-hydroxy-5-methyl-4-isoxazolepropionic acid (AMPA) receptors from the cell membrane. Thus, a DNA methylation in the genome region upstream of the Arc is differentially regulated through the critical period of song development. In canaries, the gene induction of histone $H 3.3 B$ and Gadd45b is higher in robust nucleus of the arcopallidum $(R A)$ of those birds that interpret variable and plastic songs than in birds singing crystallized songs ${ }^{[10]}$. In addition, microRNAs (miRs) are of special interest, with the ability to regulate neurogenesis and thereby contributing to the organization of the brain structures underlying speech and vocal learning. In songbirds, miRs may have activating effects that support vocal learning and multiple miRs affect neurite growth and synaptogenesis ${ }^{[198]}$. For instance, the expression of $5 \mathrm{miRs}$ in cortical auditory regions is affected by exposure to the specific song. In this way, miR-92, -124, and $-129-5 p$ decrease, and $m i R-25$ and -192 increase ${ }^{[199]}$. miR-124 and $m i R-137$ conduct cell differentiation to a neural destination by suppressing non-neuronal transcriptions or regulate the maturation of neurons ${ }^{[200-202]}$.

As epigenetic mechanisms in Foxp2, miR-9, $-132^{[203]}$ and -140-5p express in the area $X$ of the zebra finch and positively regulate by singing in young and adults, associated with reduced levels of Foxp ${ }^{[204]}$. miR-9 is express in postmitotic cortical neuron and induces or limits axon growth. It also acts through regulating Foxp1 to target the motor neuron specification or promotes neural differentiation by suppressing proteins involved in neural stem cell proliferation. miR-9, as a Foxp2 /miR-9 feedback loop, indirectly affects gene expression downstream of Foxp $2^{[199]}$. The other miRs control neural maturation ${ }^{[203,204]}$. miR-3666 is another factor that regulates FOXP2 levels in neurodevelopment and may contribute to the pathogenesis of neurological disorders such as schizophrenia and autism ${ }^{[198]}$. Moreover, Histone variant $\mathrm{H} 3.3$ and $\mathrm{miR}$ 128 are involved in learned vocal communication ${ }^{[199]}$. In FOXP2 $3^{\prime}$ untranslated region, let-7a, miR-9, and miR129-5p regulate its expression ${ }^{[201,205]}$. Active neuronal enhancers were predicted by strong histone-3-lysine-4monomethylation $\left(\mathrm{H}_{3} \mathrm{~K} 4 \mathrm{Me} \mathrm{l}\right)$ and histone-3-lysine27-acetylation $\left(\mathrm{H}_{3} \mathrm{~K} 2 \mathrm{AAc}\right)$ within the $3 \mathrm{C}$ fragments at 330 and $843 \mathrm{~kb}$. The $3 \mathrm{C}$ fragment at $-37 \mathrm{~kb}$ encompassed a weak neural enhancer, predicted by strong $\mathrm{H} 3 \mathrm{~K} 4 \mathrm{Me} 1$ and weak $H_{3} K 27 A c$. In some neuronal roadmap epigenomics samples parts of the same fragment were annotated as active transcriptional start sites, predicted by an absence of $\mathrm{H}_{3} \mathrm{~K} 4 \mathrm{Mel}$ and strong $\mathrm{H}_{3} \mathrm{~K}_{9 \mathrm{~A}} \mathrm{c}^{[202]}$. Furthermore, amongst the 61 peaks with human-specific loss of $\mathrm{H}_{3} \mathrm{~K} 4 m e 3$ is a $700-b p$ sequence upstream of FOXP2 transcription start site (TSS ${ }^{[206]}$. In songbirds, unlike Foxp2, whose differential expression at the core of the song depends on behavior, the Foxp1 signaling pathway regulates the singing process, with $m R N A$ enrichment in the surrounding tissues of area $X$ of male birds, high-level vocal center nucleus $(H V C)$ and $R A^{[203]}$.

Regarding epigenetic factors involved in the different speech and language disorders, in silico tests identified as factors implicated in the development of CAS to miR-182, miR-34c-5p, miR-34a, miR-449a, miR-449b, miR1271, $m i R-96, m i R-9, m i R-647, m i R-604, m i R-214$, and $m i R-657^{[207]}$. The same author implicated in $D L D$ to $m i R-1207-5 p$, $m i R-188-3 p$, $m i R-1225-3 p$, and $m i R-299-3 p^{[207]}$. Epigenetic mechanisms may affect the expression of KIAA0319 in the etiology of dyslexia. For instance, $m i R-548 c-3 p$, may define the development of $D L^{[208]}$. Concerning $A S D$, it was reported a hypermethylation at oxytocin receptor gene (OXTR) in peripheral blood, and the temporal cortex of patient ${ }^{[209]}$. As epigenetic mechanisms of FXS, a promoter hypermethylation induces a transcription repression ${ }^{[64]}$. An increased methylation at site $\mathrm{H}_{3} \mathrm{~K} 9$ and $\mathrm{H}_{3} \mathrm{~K} 27$, which modify transcription activation, have been reported in $H D^{[64]}$.

\section{CONCLUSION}

1. Multiple genes involved in speech and language have been reported. FOXP1, FOXP2, CMIP or GNPTAB are genes in which associations have been replicated. However, in other genes, further studies are needed to demonstrate their linkage. The unification of criteria, the development of endophenotypes or observational studies of genetic variants, such as GWAS, are needed to provide more robust results. 
2. Epigenetic factors modulate verbal communication. Songbird studies bring a better understanding of the human communication process. In silico predictive analysis can identify the epigenetic factors involved in disorders of speech and language.

3. Their mechanisms of action have not been fully elucidated and there are several molecular pathways involved in communication that interact with each other.

4. Speech and language disorders may be inherited or syndromic, associated or not with neurological and psychiatric disorders. In associated cases, identifying genes may be useful for an early diagnosis or predicting the disease progression.

\section{DECLARATIONS}

\section{Authors' contributions}

Made substantial contributions to conception and design of the review and interpretation: Guerra J

Read, adjusted and approved the final manuscript: Cacabelos $\mathrm{R}$

\section{Availability of data and materials}

Not applicable.

\section{Financial support and sponsorship}

None.

\section{Conflicts of interest}

Both authors declared that there are no conflicts of interest.

\section{Ethical approval and consent to participate}

Not applicable.

\section{Consent for publication}

Not applicable.

\section{Copyright}

(c) The Author(s) 2019.

\section{REFERENCES}

1. Konopka G, Roberts T. Insights into the neural and genetic basis of vocal communication. Cell 2016;164:1269-76.

2. Cortical language areas. University of Minnesota Duluth. Available from: http://www.d.umn.edu/ jfitzake/Lectures/DMED/ SpeechLanguage/CorticalS_LAreas/CorticalLanguageAreas.html. [Last accessed on 11 Jun 2019]

3. Friederici AD. The brain basis of language processing: from structure to function. Physiol Rev 2011;91:1357-92.

4. Starowicz-Filip A, Chrobak A, Moskała M, Krzyżewski RM, Kwinta B, et al. The role of the cerebellum in the regulation of language functions. Psychiatr Pol 2017;51:661-71

5. Kang C, Drayna D. Genetics of speech and language disorders. Annu Rev Genomics Hum Genet 2011;12:145-64.

6. Newbury DF, Monaco AP. Genetic advances in the study of speech and language disorders. Neuron 2010;68:309-20.

7. Szalontai A, Csiszar K. Genetic insights into the functional elements of language. Hum Genet 2013;132:959-86.

8. Rice M, Smolík F. Genetics of language disorders: clinical conditions, phenotypes, and genes. In: Gaskell G, editor. The Oxford Handbook of Psycholinguistics. Oxford Handbooks Online; 2007.

9. Mori C, Wada K. Songbird: a unique animal model for studying the molecular basis of disorders of vocal development and communication. Exp Anim 2015;64:221-30.

10. Wada K, Kobayashi M, Wan-Chun L. Epigenetic gene expression dynamics induced by singing in a critical period of vocal learning. Front Behav Neurosci 2012;6.

11. Ropper A, Samuels M, Klein J. Disorders of speech and language. In: Victor M, Ropper AH, editors. Adams and Victor's principles of 
Neurology. New York: McGraw-Hill Education Medical; 2014. Pp. 486-506.

12. Dysarthria in adults: overview - ASHA. Available from: https://www.asha.org/Practice-Portal/Clinical-Topics/Dysarthria-in-Adults/. [Last accessed on 11 Jun 2019]

13. McDonald C. Clinical approach to the diagnostic evaluation of hereditary and acquired neuromuscular diseases. Phys Med Rehabil Clin N Am 2012;23:495-563.

14. Alseth EH. Genetic associations in myasthenia gravis Implications for pathogenesis. PhD. University of Bergen; 2010.

15. Online Mendelian Inheritance in Man, OMIM (TM). Johns Hopkins University, Baltimore, MD. OMIM Number: $\{254200\}:\{10 / 04 / 2013\}$. Available from: http://www.ncbi.nlm.nih.gov/omim/. [Last accessed on 11 Jun 2019]

16. Zagoriti Z, Kambouris M, Patrinos G, Tzartos SJ, Poulas K. Recent advances in genetic predisposition of myasthenia gravis. Biomed Res Int 2013;2013:1-12.

17. Sanders D. CS1.1 Seronegative and MuSK antibody-positive myasthenia gravis. Clin Neurophysiol 2006;117:1.

18. Beukelman D, Fager S, Nordness A. Communication support for people with ALS. Neurol Res Int 2011;2011:714693.

19. Lewis BA. 2006 Speech and language disorders associated with Prader-Willi syndrome. In: Butler MG, Lee PDK, Whitman BY, editors. Management of Prader-Willi syndrome. 3rd ed. New York: Springer; 2006. pp. 272-83.

20. Bird TD. Hereditary Ataxia Overview. Available from: https://www.ncbi.nlm.nih.gov/books/NBK1138/. [Last accessed on 10 Jun 2019]

21. Orr H, Zoghbi H. Trinucleotide repeat disorders. Annu Rev Neurosci 2007;30:575-621.

22. Brendel B, Synofzik M, Ackermann H, Lindig T, Schölderle T, et al. Comparing speech characteristics in spinocerebellar ataxias type 3 and type 6 with Friedreich ataxia. J Neurol 2014;262:21-6.

23. Sidtis J, Ahn J, Gomez C, Sidtis D. Speech characteristics associated with three genotypes of ataxia. J Commun Disord 2011;44:478-92.

24. Gómez-Coello A, Valadez-Jiménez V, Cisneros B, Carrillo-Mora P, Parra-Cárdenas M, et al. Voice alterations in patients with spinocerebellar ataxia type 7 (SCA7): Clinical-Genetic Correlations. J Voice 2017;31:123e1-5.

25. Brendel B, Ackermann H, Berg D, Lindig T, Schölderle T, et al. Friedreich ataxia: dysarthria profile and clinical data. Cerebellum 2013;12:475-84.

26. Hereditary spastic paraplegia overview - NCBI - NIH . Available from: https://www.ncbi.nlm.nih.gov/books/NBK1509/. [Last accessed on 11 Jun 2019]

27. Clinical Bulletin in Dysarthria. Available from: https://www.nationalmssociety.org/NationalMSSociety/media/MSNationalFiles/Brochures/ Clinical-Bulletin-Dysarthria.pdf. [Last accessed on 11 Jun 2019]

28. Feenaughty L, Tjaden K, Benedict R, Weinstock-Guttman B. Speech and pause characteristics in multiple sclerosis: a preliminary study of speakers with high and low neuropsychological test performance. Clin Linguist Phon 2013;27:134-51.

29. Hartelius L, Runmarker B, Andersen O. Prevalence and characteristics of dysarthria in a multiple-sclerosis incidence cohort: relation to neurological data. Folia Phoniatr Logop 2000;52:160-77.

30. Online Mendelian Inheritance in Man, OMIM (TM). Johns Hopkins University, Baltimore, MD. OMIM Number: $\{126200\}:\{07 / 18 / 2018\}$. Available from: http://www.ncbi.nlm.nih.gov/omim/. [Last accessed on 11 Jun 2019]

31. Hrastelj J, Robertson N. Genetics of disease severity in multiple sclerosis, Alzheimer's disease, and Huntington's disease: rejuvenating genome-wide association studies. J Neurol 2017;264:2040-2.

32. González S, Rojas J, Redal M, Patrucco L, Correale J, et al. CD24 as a genetic modifier of disease progression in multiple sclerosis in Argentinean patients. J Neurol Sci 2011;307:18-21.

33. Zhou Q, Rammohan K, Lin S, Robinson N, Li O, et al. CD24 is a genetic modifier for risk and progression of multiple sclerosis. Proc Nat Acad Sci 2003;100:15041-6.

34. Sadovnick A, Traboulsee A, Zhao Y, Bernales CQ, Encarnacion M, et al. Genetic modifiers of multiple sclerosis progression, severity and onset. Clin Immunol 2017;180:100-5.

35. Kroner A, Mehling M, Hemmer B, Rieckmann P, Toyka KV. A PD-1 polymorphism is associated with disease progression in multiple sclerosis. Ann Neurol 2005;58:50-7.

36. Online Mendelian Inheritance in Man, OMIM (TM). Johns Hopkins University, Baltimore, MD. OMIM Number: $\{163890\}:\{06 / 27 / 2018\}$. Available from: http://www.ncbi.nlm.nih.gov/omim/. [Last accessed on 11 Jun 2019]

37. Diao J, Burré J, Vivona S, Cipriano DJ, Sharma M, et al. Native $\alpha$-synuclein induces clustering of synaptic-vesicle mimics via binding to phospholipids and synaptobrevin-2/VAMP2. Elife 2013;2.

38. Kelm-Nelson C, Yang K, Ciucci M. Exercise effects on early vocal ultrasonic communication dysfunction in a PINK1 knockout model of Parkinson's disease. J Parkinsons Dis 2015;5:749-63.

39. Grant L, Richter F, Miller J, White SA, Fox CM, et al. Vocalization deficits in mice over-expressing alpha-synuclein, a model of premanifest Parkinson's disease. Behav Neurosci 2014;128:110-21.

40. Creed R, Goldberg M. New developments in genetic rat models of Parkinson's disease. Mov Disord 2018;33:717-29.

41. Pultorak J, Kelm-Nelson C, Holt L, Blue KV, Ciucci MR, et al. Decreased approach behavior and nucleus accumbens immediate early gene expression in response to Parkinsonian ultrasonic vocalizations in rats. Soc Neurosci 2015;11:365-79.

42. Zheng Y, Pei Z, Liu Y, Zhou H, Xian W, et al. Cognitive impairments in LRRK2-related Parkinson's disease: a study in Chinese Individuals. Behav Neurol 2015;2015:1-5.

43. García A, Sedeño L, Trujillo N, Bocanegra Y, Gómez D, et al. Language deficits as a preclinical window into Parkinson’s disease: evidence from asymptomatic parkin and dardarin mutation carriers. J Int Neuropsychol Soc 2017;23:150-8.

44. Tanner K, Roy N, Merrill R, Kimber K, Sauder C, et al. Risk and protective factors for spasmodic dysphonia: a case-control investigation. J Voice 2011;25:e35-46. 
45. Breakefield XO, Blood AJ, Li Y, Hallett M, Hanson PI, et al. The pathophysiological basis of dystonias. Nat Rev Neurosci 2008;9:222-34.

46. Bianchi S, Battistella G, Huddleston H, Shcharf R, Fleysher L, et al. Phenotype- and genotype-specific structural alterations in spasmodic dysphonia. Mov Disord 2017;32:560-8.

47. Simonyan K, Tovar-Moll F, Ostuni J, Hallett M, Kalasinsky VF, et al. Focal white matter changes in spasmodic dysphonia: a combined diffusion tensor imaging and neuropathological study. Brain 2008;131:447-59.

48. Blitzer A, Brin M, Simonyan K, Ozelious LJ, Frucht SJ, et al. Phenomenology, genetics, and CNS network abnormalities in laryngeal dystonia: a 30-year experience. Laryngoscope 2017;128:S1-9.

49. Simonyan K, Ludlow C. Abnormal activation of the primary somatosensory cortex in spasmodic dysphonia: an fMRI study. Cereb Cortex 2010;20:2749-59.

50. Putzel G, Fuchs T, Battistella G, Rubien-Thomas E, Frucht SJ, et al. GNAL mutation in isolated laryngeal dystonia. Mov Disord 2016;31:750-5.

51. Sharma N, Franco R. Consideration of genetic contributions to the risk for spasmodic dysphonia. Otolaryngol Head Neck Surg 2011;145:369-70.

52. Putzel G, Battistella G, Rumbach, A Ozelius LJ, Sabuncu MR, et al. Polygenic risk of spasmodic dysphonia is associated with vulnerable sensorimotor connectivity. Cereb Cortex 2016;28:158-66.

53. Ludlow C. Spasmodic dysphonia: a laryngeal control disorder specific to speech. J Neurosci 2011;31:793-7.

54. Clarimon J, Asgeirsson H, Singleton A, Jakobsson F, Hjaltason H, et al. Torsin A haplotype predisposes to idiopathic dystonia. Ann Neurol 2005;57:765-7.

55. Hague S, Klaffke S, Clarimon J, Hemmer B, Singleton A, et al. Lack of association with TorsinA haplotype in German patients with sporadic dystonia. Neurology 2006;66:951-2.

56. Sharma N, Franco RA, Kuster J, Mitchel AA, Fuchs T, et al. Genetic evidence for an association of the TOR1A locus with segmental/focal dystonia. Mov Disord 2010;25:2183-7.

57. Lohmann K, Wilcox R, Winkler S, Ramirez A, Rakovic A, et al. Whispering dysphonia (DYT4 dystonia) is caused by a mutation in the TUBB4 gene. Ann Neurol 2013;73:537-45.

58. Peng Y, Crumley R, Ringman J. Spasmodic dysphonia in a patient with the A to G transition at nucleotide 8344 in mitochondrial DNA. Mov Disord 2003;18:716-8.

59. Qi Y, Zheng Y, Li Z, Xiong L. Progress in genetic studies of Tourette's syndrome. Brain Sci 2017;7:134.

60. Belloso J, Bache I, Guitart M, Caballin MR, Halgren C, et al. Disruption of the CNTNAP2 gene in a t $(7 ; 15)$ translocation family without symptoms of Gilles de la Tourette syndrome. Eur J Hum Genet 2007;15:711-3.

61. Sun N, Nasello C, Deng L, Wang N, Zhang Y, et al. The PNKD gene is associated with Tourette Disorder or Tic disorder in a multiplex family. Mol Psychiatry 2017;23:1487-1495.

62. Hamilton A, Ferm U, Heemskerk A, Twiston-Davies R, Matheson KY, et al. Management of speech, language and communication difficulties in Huntington's disease. Neurodegener Dis Manag 2012;2:67-77.

63. Smith S. Approach to epigenetic analysis in language disorders. J Neurodev Disord 2011;3:356-64.

64. Valor L. Transcription, Epigenetics and Ameliorative Strategies in Huntington's Disease: a Genome-Wide Perspective. Mol Neurobiol 2014;51:406-23.

65. Patel A, Frucht S. Isolated vocal tremor as a focal phenotype of essential tremor: a retrospective case review. J Clin Mov Disord 2015;2:2-4.

66. Sulica L, Louis E. Clinical characteristics of essential voice tremor: a study of 34 cases. Laryngoscope 2010;120:516-28.

67. Online Mendelian Inheritance in Man, OMIM (TM). Johns Hopkins University, Baltimore, MD. OMIM Number: $\{190300\}:\{02 / 16 / 2016\}$. Available from: http://www.ncbi.nlm.nih.gov/omim/. [Last accessed on 11 Jun 2019]

68. Frigerio-Domingues C, Drayna D. Genetic contributions to stuttering: the current evidence. Mol Genet Genomic Med 2017;5:95-102.

69. Kazemi N, Estiar M, Fazilaty H, Sakhinia E. Variants in GNPTAB, GNPTG and NAGPA genes are associated with stutterers. Gene 2018;647:93-100.

70. Online Mendelian Inheritance in Man, OMIM (TM). Johns Hopkins University, Baltimore, MD. OMIM Number: $\{607840\}:\{03 / 07 / 2018\}$. Available from: http://www.ncbi.nlm.nih.gov/omim/. [Last accessed on 11 Jun 2019]

71. Raza MH, Gertz EM, Mundorff J, Lukong J, Kuster J, et al. Linkage analysis of a large African family segregating stuttering suggests polygenic inheritance. Hum Genet 2013;132:385-96.

72. Suresh R, Ambrose N, Roe C, Pluzhnikov A, Wittke-Thompson JK, et al. New complexities in the genetics of stuttering: significant sex $\square$ specific linkage signals. Am J Hum Genet 2006;78:554-63.

73. Domingues CE, Olivera CM, Oliveira BV, Juste FS, Andrade CR, et al. A genetic linkage study in Brazil identifies a new locus for persistent developmental stuttering on chromosome 10. Genet Mol Res 2014;13:2094-101.

74. Lan J, Song M, Pan C, Zhuang G, Wang Y, et al. Association between dopaminergic genes (SLC6A3 and DRD2) and stuttering among Han Chinese. J Hum Genet 2009;54:457-60.

75. Reuter M, Riess A, Moog U, Briggs TA, Chandler KE, et al. FOXP2 variants in 14 individuals with developmental speech and language disorders broaden the mutational and clinical spectrum. J Med Genet 2016;54:64-72.

76. Petrin A, Giacheti C, Maximino L, Abramides D, Zanchetta S, et al. Identification of a microdeletion at the 7q33-q35 disrupting the CNTNAP2 gene in a Brazilian stuttering case. Am J Med Gen A 2010;152A:3164-72.

77. Dauer K, Irwin S, Schippits S. Becoming verbal and intelligible: a functional motor programming approach for children with developmental verbal apraxia. Harcourt Publishers Ltd; 1996. 
78. Rosenbek JC, Wertz RT, LaPointe LL. Apraxia of speech in adults: the disorder and its management. Grune \& Stratton, New York; 1984.

79. Graham S, Fisher S. Understanding language from a genomic perspective. Annu Rev Genet 2015;49:131-60.

80. Lai CS, Fisher SE, Hurst JA, Vargha-Khadem F, Monaco AP. A forkhead-domain gene is mutated in a severe speech and language disorder. Nature 2001;413:519-23.

81. Bacon C, Rappold G. The distinct and overlapping phenotypic spectra of FOXP1 and FOXP2 in cognitive disorders. Hum Genet 2012;131:1687-98.

82. Oswald F, Klöble P, Ruland A, Rosenkranz D, Hinz B, et al. The FOXP2-driven network in developmental disorders and neurodegeneration. Front Cell Neurosci 2017;11:212.

83. Becker M, Devanna P, Fisher S, Vernes SC. Mapping of human FOXP2 enhancers reveals complex regulation. Front Mol Neurosci. 2018;11:47.

84. Liégeois F, Hildebrand M, Bonthrone A, Turner SJ, Scheffer IE, et al. Early neuroimaging markers of FOXP2 intragenic deletion. Sci Rep 2016;6:35192.

85. Morgan A, Fisher SE, Scheffer I, Hildebrand M. FOXP2-related speech and language disorders. 2016 Jun 23 [Updated 2017 Feb 2]. In: Adam MP, Ardinger HH, Pagon RA, Wallace SE, Bean LJH, et al., editors. GeneReviews ${ }^{\circledR}$ [Internet]. Seattle (WA): University of Washington, Seattle; 1993-2018. Available from: https://www.ncbi.nlm.nih.gov/books/NBK368474/. [Last accessed on 11 Jun 2019]

86. Hamdan F, Daoud H, Rochefort D, Piton A, Gauthier J, et al. De novo mutations in FOXP1 in cases with intellectual disability, autism, and language impairment. Am J Hum Genet 2010;87:671-8.

87. Le Fevre A, Taylor S, Malek N, Horn D, Carr CW, et al. FOXP1 mutations cause intellectual disability and a recognizable phenotype. Am J Med Genet Part A 2013;161:3166-75.

88. Peter B, Wijsman EM, Nato AQ, Matsushita MM, Chapman KL, et al. Genetic Candidate variants in two multigenerational families with childhood apraxia of speech. PLoS One 2016;11:e0153864.

89. Eising E, Carrion-Castillo A, Vino A, Strand EA, Jakielski KJ, et al. A set of regulatory genes co-expressed in embryonic human brain is implicated in disrupted speech development. Mol Psychiatry 2018; doi: 10.1038/s41380-018-0020-x.

90. Worthey E, Raca G, Laffin J, Wilk BM, Harris JM, et al. Whole-exome sequencing supports genetic heterogeneity in childhood apraxia of speech. J Neurodev Disord 2013;5:29.

91. Thevenon J, Callier P, Andrieux J, Delobel B, David A, et al. 12p13.33 microdeletion including ELKS/ERC1, a new locus associated with childhood apraxia of speech. Eur J Hum Genet 2012;21:82-8.

92. Laffin J, Raca G, Jackson C, Strand EA, Jakielski KJ, et al. Novel candidate genes and regions for childhood apraxia of speech identified by array comparative genomic hybridization. Genet Med 2012;14:928-36.

93. Newbury D, Mari F, Sadighi-Akha E, Macdermot KD, Canitano R, et al. Dual copy number variants involving 16p11 and 6q22 in a case of childhood apraxia of speech and pervasive developmental disorder. Eur J Hum Genet 2012;21:361-5.

94. Bauman-Wängler J. Articulatory and phonological impairments: a clinical focus. 2nd ed. Boston: Allyn and Bacon; 2004.

95. Hayiou-Thomas M, Carroll J, Leavett R, Hulme C, Snowling MJ. When does speech sound disorder matter for literacy? The role of disordered speech errors, co-occurring language impairment and family risk of dyslexia. J Child Psychol Psychiatry 2016;58:197-205.

96. Eicher J, Stein C, Deng F, Ciesla AA, Powers NR, et al. The DYX2 locus and neurochemical signaling genes contribute to speech sound disorder and related neurocognitive domains. Genes Brain Behav 2015;14:377-85.

97. Nopola-Hemmi J, Myllyluoma B, Haltia T, Taipale M, Ollikainen V, et al. A dominant gene for developmental dyslexia on chromosome 3. J Med. Genet 2001;38:658-64.

98. Kraft S, De Thorne L. The brave new world of epigenetics: embracing complexity in the study of speech and language disorders. Curr Dev Disord Rep 2014;1:207-14

99. Anthoni H, Sucheston LE, Lewis BA, Tapia-Páez I, Fan X, et al. The aromatase Gene CYP19A1: several genetic and functional lines of evidence supporting a role in reading, speech and language. Behav Gen 2012;42:509-27.

100. Panjwani N, Wilson MD, Addis L, Crosbie J, Wirrell E, et al. A microRNA-328 binding site in PAX6 is associated with centrotemporal spikes of rolandic epilepsy. Ann Clin Transl Neurol 2016;3:512-22.

101. Tang-Wai D, Graham N. Assessment of language function in dementia. Available from: https://www.medscape.com/viewarticle/573859_4. [Last accessed on 11 Jun 2019]

102. Tai L, Thomas R, Marottoli F, Koster KP, Kanekiyo T, et al. The role of APOE in cerebrovascular dysfunction. Acta Neuropathol 2016;131:709-23.

103. Kim J, Basak J, Holtzman D. The role of apolipoprotein E in Alzheimer's disease. Neuron 2009;63:287-303.

104. Cacace R, Sleegers K, Van-Broeckhoven C. Molecular genetics of early-onset Alzheimer's disease revisited. Alzheimers Dement 2016;12:733-48.

105. Mez J, Cosentino S, Brickman A, Huey ED, Mayeux R. Different demographic, genetic, and longitudinal traits in language versus memory Alzheimer's subgroups. J Alzheimers Dis 2013;37:137-46.

106. Premi E, Pilotto A, Alberici A, Papetti A, Archetti S, et al. FOXP2, APOE, and PRNP: new modulators in primary progressive aphasia. J Alzheimers Dis 2012;28:941-50.

107. Daniele A, Matera M, Seripa D, Acciarri A, Bizzarro A, et al. APOE $\varepsilon 2 / \varepsilon 4$ genotype a risk factor for primary progressive aphasia in women. Arch Neurol 2009;66:910-2.

108. Seripa D, Bizzarro A, Pilotto A, Palmieri O, Panza F, et al. TOMM40, APOE, and APOC1 in primary progressive aphasia and frontotemporal dementia. J Alzheimers Dis 2012;31:731-40.

109. Deters K, Nho K, Risacher S, Kim S, Ramanan VK, et al. Genome-wide association study of language performance in Alzheimer's disease. 
Brain Lang 2017;172:22-9.

110. Padovani A, Cosseddu M, Premi E, Archetti S, Papetti A, et al. The speech and language FOXP2 gene modulates the phenotype of frontotemporal lobar degeneration. J Alzheimers Dis 2010;22:923-31.

111. Rogalski E, Weintraub S, Mesulam M. Are there susceptibility factors for primary progressive aphasia? Brain Lang 2013;127:135-8.

112. Flanagan, EP, Baker MC, Perkerson RB, Duffy JR, Strand EA, et al. Dominant frontotemporal dementia mutations in 140 cases of primary progressive aphasia and speech apraxia. Dement Geriatr Cogn Disord 2015;39:281-6.

113. Bishop D. Uncommon understanding: development and disorders of language comprehension in children. East Sussex: Psychology Press; 1997.

114. Poliak S, Gollan L, Martinez R, Custer A, Einheber S, et al. Caspr2, a new member of the neurexin superfamily, is localized at the juxtaparanodes of myelinated axons and associates with K+ Channels. Neuron 1999;24:1037-47.

115. Toma C, Pierce KD, Shaw AD, Heath A, Mitchell PB, et al. Comprehensive cross-disorder analyses of CNTNAP2 suggest it is unlikely to be a primary risk gene for psychiatric disorders. PLoS Genet 2018;14:e1007535.

116. Trajkovski V. Medical genetics and its implementation in speech, language and hearing disorders. In: Milošević N, editor. II Congress of Logopedists of Serbia. Belgrade, Serbia: Association of logopedists of Serbia; 2015.

117. Centanni TM, Sanmann JN, Green JR, Iuzzini-Seigel J, Bartlett C, et al. The role of candidate-gene CNTNAP2 in childhood apraxia of speech and specific language impairment. Am J Med Genet B Neuropsychiatr Genet 2015;168:536-43.

118. Strauss KA, Puffenberger EG, Huentelman MJ, Gottlieb S, Dobrin SE, et al. Recessive symptomatic focal epilepsy and mutant contactinassociated protein-like 2. N Eng J Med 2006;354:1370-7.

119. Condro MC, White SA. Distribution of language-related Cntnap2 protein in neural circuits critical for vocal learning. J Comp Neurol 2014;522:169-85.

120. Newbury DF, Winchester L, Addis L, Paracchini S, Buckingham LL, et al. CMIP and ATP2C2 modulate phonological short-term memory in language impairment. Am J Human Genet 2009;85:264-72.

121. Lesch KP, Timmesfeld N, Renner TJ, Halperin R, Roser C, et al. Molecular genetics of adult ADHD: converging evidence from genomewide association and extended pedigree linkage studies. J Neural Transm 2008;115:1573-85.

122. Newbury D, Monaco A. Genetic advances in the study of speech and language disorders. Neuron 2010;68:309-20.

123. Filges I, Shimojima K, Okamoto N, Röthlisberger B, Weber P, et al. Reduced expression by SETBP1 haploinsufficiency causes developmental and expressive language delay indicating a phenotype distinct from Schinzel-Giedion syndrome. J Med Genet 2010;48:11722.

124. Marseglia G, Scordo M, Pescucci C, Nannetti G, Biagini E, et al. 372 kb microdeletion in 18q12.3 causing SETBP1 haploinsufficiency associated with mild mental retardation and expressive speech impairment. Eur J Med Genet 2012;55:216-21.

125. Luciano M, Evans DM, Hansell NK, Medland SE, Montgomery GW, et al. A genome-wide association study for reading and language abilities in two population cohorts. Genes Brain Behav 2013;12:645-52.

126. Gialluisi A, Newbury DF, Wilcutt EG, Olson RK, DeFries JC, et al. Genome-wide screening for DNA variants associated with reading and language traits. Genes Brain Behav 2014;13:686-701.

127. St Pourcain B, Cents RA, Whitehouse AJ, Haworth CM, Davis OS, et al. Common variation near ROBO2 is associated with expressive vocabulary in infancy. Nat Commun 2014;5:4831.

128. Eicher JD, Powers NR, Miller LL, Akshoomoff N, Amaral DG, et al. Genome-wide association study of shared components of reading disability and language impairment. Genes Brain Behav 2013;12:792-801.

129. Nudel R, Simpson NH, Baird G, O’Hare A, Conti-Ramsden G, et al. Genome-wide association analyses of child genotype effects and parent-of-origin effects in specific language impairment. Genes Brain Behav 2014;13:418-29.

130. Villanueva P, Nudel R, Hoischen, A, Fernández MA, Simpson NH, et al. Exome sequencing in an admixed isolated population indicates NFXL1 variants confer a risk for specific language impairment. PLoS Genet 2015;11:e1004925.

131. Kalnak N, Stamouli S, Peyrard-Janvid M, Rabkina I, Becker M, et al. Enrichment of rare copy number variation in children with developmental language disorder. Clin Genet 2018;94:313-20.

132. Ercan-Sencicek A, Davis-Wright N, Sanders S, Oakman N, Valdes L, et al. A balanced $t(10 ; 15)$ translocation in a male patient with developmental language disorder. Eur J Med Genet 2012;55:128-31.

133. Kuppen S, Goswami U. Developmental trajectories for children with dyslexia and low IQ poor readers. Dev Psychol 2016;52:717-34.

134. What are reading disorders? NICHD - Eunice Kennedy Shriver- NIH. Available from: https://www.nichd.nih.gov/health/topics/reading/ conditioninfo/disorders. [Last accessed on 11 Jun 2019]

135. Catts H. Defining dyslexia as a developmental language disorder. Ann Dyslexia 1989;39:50-64.

136. Paloyelis Y, Rijsdijk F, Wood A, Asherson P, Kuntsi J. The genetic association between ADHD symptoms and reading difficulties: the role of inattentiveness and IQ. J Abnor Child Psychol 2010;38:1083-95.

137. Germanò E, Gagliano A, Curatolo P. Comorbidity of ADHD and dyslexia. Devl Neuropsychol 2010;35:475-93.

138. Kere J. The molecular genetics and neurobiology of developmental dyslexia as model of a complex phenotype. Biochem Biophys Res Commun 2014;452:236-43.

139. Fagerheim T, Raeymaekers P, Tønnessen FE, Pedersen M, Tranebjaerg L, et al. A new gene (DYX3) for dyslexia is located on chromosome 2. J Med Genet 1999;36:664-9.

140. Massinen S, Wang J, Laivuori K, Bieder A, Tapia Paez I, et al. Genomic sequencing of a dyslexia susceptibility haplotype encompassing ROBO1. J Neurodev Disord 2016;27;8:4.

141. Fisher SE, Francks C, Marlow AJ, MacPhie IL, Newbury DF, et al. Independent genome-wide scans identify a chromosome 18 quantitative- 
trait locus influencing dyslexia. Nat Genet 2002;30:86-91.

142. Tzenova J, Kaplan BJ, Petryshen TL, Field LL. Confirmation of a dyslexia susceptibility locus on chromosome 1p34-p36 in a set of 100 Canadian families. Am J Med Genet B Neuropsychiatr Genet 2004;127B:117-24.

143. De Kovel CG, Hol FA, Heister JG, Willemen JJ, Sandkuijl LA, et al. Genomewide scan identifies susceptibility locus for dyslexia on Xq27 in an extended Dutch family. J Med Genet 2004;41:652-7.

144. Taipale M, Kaminen N, Nopola-Hemmi J, Haltia T, Myllyluoma B, et al. A candidate gene for developmental dyslexia encodes a nuclear tetratricopeptide repeat domain protein dynamically regulated in brain. Proc Natl Acad Sci USA 2003;100:11553-8.

145. Lim CK, Ho CS, Chou CH, Wayne MM. Association of the rs3743205 variant of DYX1C1 with dyslexia in Chinese children. Behav Brain Funct 2011;7:16.

146. Massinen S, Tammimies K, Tapia-Paez I, Matsson H, Hokkanen ME, et al. Functional interaction of DYX1C1 with estrogen receptors suggests involvement of hormonal pathways in dyslexia. Hum Mol Genet 2009;18: 2802-12.

147. Moffat JJ, Ka M, Jung EM, Kim WY. Genes and brain malformations associated with abnormal neuron positioning. Mol Brain $2015 ; 8: 72$.

148. Raskind W, Peter B, Richards T, Eckert MM, Berninger VW. The genetics of reading disabilities: from phenotypes to candidate genes. Front Psychol 2013;3:601.

149. Meng H, Smith SD, Hager K, Held M, Liu J, et al. DCDC2 is associated with reading disability and modulates neuronal development in the brain. Proc Natl Acad Sci USA 2005;102:17053-8.

150. Scerri TS, Macpherson E, Martinelli A, Wa WC, Monaco AP, et al. The DCDC2 deletion is not a risk factor for dyslexia. Transl Psychiatry 2017;25:7:e1182.

151. Chen Y, Zhao H, Zhang YX, Zuo PX. DCDC2 gene polymorphisms are associated with developmental dyslexia in Chinese Uyghur children. Neural Regen Res 2017;12:259-266.

152. Francks C, Paracchini S, Smith SD, Richardson AJ, Scerri TS, et al. A 77-kilobase region of chromosome 6p22.2 is associated with dyslexia in families from the United Kingdom and from the United States. Am J Hum Genet 2004; 75:1046-58.

153. Harold D, Paracchini S, Scerri T, Dennis M, Cope N, et al. Further evidence that the KIAA0319 gene confers susceptibility to developmental dyslexia. Mol Psychiatry 2006;11:1085-91, 1061.

154. Scerri TS, Morris AP, Buckingham LL, Newbury DF, Miller LL, et al. DCDC2, KIAA0319 and CMIP are associated with reading-related traits. Biol Psychiatry 2011;70:237-45.

155. Pinel P, Fauchereau F, Moreno A, Barbot A, Lathrop M, et al. Genetic variants of FOXP2 and KIAA0319/TTRAP/THEM2 locus are associated with altered brain activation in distinct language-related regions. J Neurosci 2012;32:817-25.

156. Sundaresan V, Mambetisaeva E, Andrews W, Annan A, Knöll B, et al. Dynamic expression patterns of Robo (Robo1 and Robo2) in the developing murine central nervous system. J Comp Neurol 2003;468:467-81.

157. Hannula-Jouppi K, Kaminen-Ahola N, Taipale M, Eklund R, Nopola-Hemmi J, et al. The axon guidance receptor gene ROBO1 is a candidate gene for developmental dyslexia. PLoS Genet 2005;1:e50.

158. Anthoni H, Zucchelli M, Matsson H, Muller-Myhsok B, Fransson I, et al. A locus on 2p12 containing the co-regulated MRPL19 and C2ORF3 genes is associated to dyslexia. Hum Mol Genet 2007;16:667-77.

159. Kim M, Roesener A, Mendonca P, Mastik GS. Robo1 and Robo2 have distinct roles in pioneer longitudinal axon guidance. Dev Biol 2011;358:181-8.

160. Landi N, Frost S, Mencl W, Preston JL, Jacobsen LK, et al. The COMT Val/Met polymorphism is associated with reading-related skills and consistent patterns of functional neural activation. Dev Sci 2012;16:13-23.

161. Scerri TS, Paracchini S, Morris A, MacPhie IL, Talcott J, et al. Identification of candidate genes for dyslexia susceptibility on chromosome 18. PLoS One 2010;5:e13712.

162. Eicher J, Powers N, Cho K, Miller LL, Mueller KL, et al. Associations of prenatal nicotine exposure and the dopamine related genes ANKK1 and DRD2 to verbal language. PLoS One 2013;8:e63762.

163. Stein C, Truitt B, Deng F, Ciesla AA, Qiu F, et al. Association between AVPR1A, DRD2, and ASPM and endophenotypes of communication disorders. Psychiatr Genet 2014;24:191-200.

164. Chen H, Wang G, Xia J, Zhou Y, Gao Y, et al. Stuttering candidate genes DRD2 but not SLC6A3 is associated with developmental dyslexia in Chinese population. Behav Brain Funct 2014;10:29.

165. Veerappa A, Padakannaya P, Ramachandra N. Copy number variation-based polymorphism in a new pseudoautosomal region 3 (PAR3) of a human X-chromosome-transposed region (XTR) in the Y chromosome. Funct Integr Genomics 2013;13:285-93.

166. Veerappa A, Saldanha M, Padakannaya P, Ramachandra NB. Family based genome-wide copy number scan identifies complex rearrangements at 17q21.31 in dyslexics. Am J Med Genet B Neuropsychiatr Genet 2014;165:572-80.

167. Gialluisi A, Visconti A, Willcutt E, Smith SD, Pennington BF, et al. Investigating the effects of copy number variants on reading and language performance. J Neurodevelop Disord 2016;8:17.

168. Craig F, Lamanna AL, Margari F, Matera E, Simone M, et al. Overlap between autism spectrum disorders and attention deficit hyperactivity disorder: searching for distinctive/common clinical features. Autism Res 2015;8:328-37.

169. Tarazi FI, Sahli ZT, Pleskow J, Mousa SA. Asperger’s syndrome: diagnosis, comorbidity and therapy. Expert Rev Neurother 2015;15:28193.

170. Mody M, Belliveau J. Speech and language impairments in autism: insights from behavior and neuroimaging. N Am J Med Sci 2012;5:157.

171. Gernsbacher M, Morson E, Grace E. Language and speech in autism. Annu Rev Linguist 2014;2:413-25.

172. Roll P, Vernes SC, Bruneau N, Cillario J, Ponsole-Lenfant M, et al. Molecular networks implicated in speech-related disorders: FOXP2 regulates the SRPX2/uPAR complex. Hum Mol Genet 2010;19:4848-60. 
173. Sia GM, Clem RL, Huganir RL. The human language-associated gene SRPX2 regulates synapse formation and vocalization in mice. Science 2013;342:987-91.

174. Soteros B, Cong Q, Palmer C, Sia GM. Sociability and synapse subtype-specific defects in mice lacking SRPX2, a language-associated gene. PLoS One 2018;13:e0199399.

175. Mariën P, Ackermann H, Adamaszek M, Barwood CH, Beaton A. Consensus paper: language and the cerebellum: an ongoing enigma. Cerebellum 2014;13:386-410.

176. Benítez-Burraco A, Murphy E. The oscillopathic nature of language deficits in autism: from genes to language evolution. Front Hum Neurosci 2016;10:120.

177. Jiménez-Romero S, Carrasco-Salas P, Benítez-Burraco A. Language and cognitive impairment associated with a novel p.Cys63Arg change in the MED13L Transcriptional Regulator. Mol Syndromol 2018;9:83-91.

178. Bartlett C, Hou L, Flax J, Hare A, Cheong SY, et al. A Genome scan for loci shared by autism spectrum disorder and language impairment. Am J Psychiatry 2014;171:72-81.

179. Chien W, Gau S, Chen C, Tsai WC, Wu YY, et al. Increased gene expression of FOXP1 in patients with autism spectrum disorders. Mol Autism 2013;4:23.

180. Li X, Hu, Z, He Y, Xiong X, Long X, et al. Association analysis of CNTNAP2 polymorphisms with autism in the Chinese Han population. Psychiatr Genet 2010;20:113-7.

181. Newbury D, Bonora E, Lamb J, Fisher SE, Lai CS, et al. FOXP2 is not a major susceptibility gene for autism or specific language impairment. Am J Hum Genet 2002;70:1318-27.

182. Toma C, Hervás A, Torrico B, Balmaña N, Salgado M, et al. Analysis of two language-related genes in autism. Psychiatr Genet 2013;23:82-5.

183. Tsai PT, Hull C, Chu Y, Greene-Colozzi E, Sadowski AR, et al. Autistic-like behaviour and cerebellar dysfunction in Purkinje cell Tsc1 mutant mice. Nature 2015;488:647-51.

184. Judson MC, Amaral DG, Levitt P. Conserved subcortical and divergent cortical expression of proteins encoded by orthologs of the autism risk gene MET. Cereb Cortex 2011;21:1613-26.

185. Sousa I, Clark T, Toma C, Kobayashi K, Choma M, et al. MET and autism susceptibility: family and case-control studies. Eur J Hum Genet 2008; 17:749-58

186. Cheung J, Petek E, Nakabayashi K, Tsui LC, Vincent JB, et al. Identification of the human cortactin-binding protein-2 gene from the autism candidate region at 7q31. Genomics 2001;78: 7-11.

187. Benayed R, Gharani N, Rossman I, Mancuso V, Lazar G, et al. Support for the homeobox transcription factor gene ENGRAILED 2 as an autism spectrum disorder susceptibility locus. Am J Hum Genet 2005;77:851-68.

188. Castermans D, Wilquet V, Parthoens E, Huysmans C, Steyaert J, et al. The neurobeachin gene is disrupted by a translocation in a patient with idiopathic autism. J Med Genet 2003;40:352-6.

189. Comings DE, Wu S, Chiu C, Muhleman DY, Sverd J. Studies of the c-Harvey-Ras gene in psychiatric disorders. Psychiatry Res 1996;63:25-32.

190. Naqvi S, Cole TY, Graham JM. Cole-Hughes macrocephaly syndrome and associated autistic manifestations. Am J Med Genet 2000;94:149-52.

191.Eicher JD, Gruen JR. Language impairment and dyslexia genes influence language skills in children with autism spectrum disorders. Autism Res 2015;8:229-34.

192. Poduri A, Evrony GD, Cai X, Walsh CA. Somatic mutation, genomic variation and neurological disease. Science 2013;341:1237758.

193. Sahin M, Sur M. Genes, circuits and precision therapies for autism and related neurodevelopmental disorders. Science 2015;350:aab3897.

194. Martin G, Klusek J, Estigarribia B, Roberts JE. Language characteristics of individuals with Down syndrome. Top Lang Disord 2009;29:112-32.

195. Eggers, K, Van Eerdenbrugh S. Speech disfluencies in children with Down Syndrome. J Commun Disord 2018;71:72-84.

196. Verheij C, Bakker C, de Graaff E, Keulemans J, Willemsen R, et al. Characterization and localization of the FMR-1 gene product associated with fragile X syndrome. Nature 1993;363:722-4.

197. Finestack L, Richmond E, Abbeduto L. Language development in individuals with Fragile X syndrome. Top Lang Disord 2009;29:133-48.

198. Condro MC, White SA. Recent advances in the genetics of vocal learning. Comp Cogn Behav Rev 2014;9:75-98.

199. Gunaratne PH, Lin YC, Benham AL, Drnevich J, Coarfa C, et al. Song exposure regulates known and novel microRNAs in the zebra finch auditory forebrain. BMC Genomics 2011;12:277.

200. Cheng LC, Pastrana E, Tavazoie M, Doetsch F. miR-124 regulates adult neurogenesis in the subventricular zone stem cell niche. Nat Neurosci 2009;12:399-408.

201. Sanuki R, Onishi A, Koike C, Muramatsu R, Watanabe S, et al. miR-124a is required for hippocampal axogenesis and retinal cone survival through Lhx2 suppression. Nat Neurosci. 2011;14:1125-34.

202. Rice ML, Smith SD, Gayán J. Convergent genetic linkage and associations to language, speech and reading measures in families of probands with Specific Language Impairment. J Neurodev Disord 2009;1:264-82.

203. Clovis Y, Enard W, Marinaro F, De Pietri Tonelli D. Convergent repression of Foxp2 3'UTR by miR-9 and miR-132 in embryonic mouse neocortex: implications for radial migration of neurons. Development 2012;139:3332-42.

204. Teramitsu I, Poopatanapong A, Torrisi S, White SA. Striatal FoxP2 is actively regulated during songbird sensorimotor learning. PLoS One 2010;5:e8548.

205. Fu L, Shi Z, Luo G, Tu W, Wang X, et al. Multiple microRNAs regulate human FOXP2 gene expression by targeting sequences in its $3^{\prime}$ untranslated region. Mol Brain 2014;7:71.

206. Shulha H, Crisci J, Reshetov D, Tushir JS, Cheung I, et al. Human-specific histone methylation signatures at transcription start sites in prefrontal neurons. PLoS Biology 2012;10:e1001427. 
207. Rudov A, Rocchi M, Accorsi A, Spada G, Procopio AD, et al. Putative miRNAs for the diagnosis of dyslexia, dyspraxia, and specific language impairment. Epigenetics 2013;8:1023-9.

208. Shi Z, Luo G, Fu L, Fang Z, Fang Z, et al. miR-9 and miR-140-5p target FoxP2 and are regulated as a function of the social context of singing behavior in zebra finches. J Neurosci 2013;33:16510-21.

209. Gregory SG, Connelly JJ, Towers AJ, Johnson J, Biscocho D, et al. Genomic and epigenetic evidence for oxytocin receptor deficiency in autism. BMC Med 2009;7:1-13. 